Portland State University

PDXScholar

7-6-1978

\title{
A Comparative Study of Communication Style in Japan and the United States as Revealed Through Content Analysis of Television Commercials
}

Noriko Huruse

Portland State University

Follow this and additional works at: https://pdxscholar.library.pdx.edu/open_access_etds

Part of the American Popular Culture Commons, Japanese Studies Commons, and the Mass Communication Commons

Let us know how access to this document benefits you.

\section{Recommended Citation}

Huruse, Noriko, "A Comparative Study of Communication Style in Japan and the United States as Revealed Through Content Analysis of Television Commercials" (1978). Dissertations and Theses. Paper 2869.

https://doi.org/10.15760/etd.2863

This Thesis is brought to you for free and open access. It has been accepted for inclusion in Dissertations and Theses by an authorized administrator of PDXScholar. Please contact us if we can make this document more accessible: pdxscholar@pdx.edu. 
AN ABSTRACT OF MEE THESIS OF Noriko Huruse for the Master Arts in Speeci Communication presented July 6; 1978.

Title: A Comparative Study of Communication style in Japan and the United States as Revealed Through Content Analysis of Television Commercials.

APPROVED BY MEMBERS OF THE THESIS COMMITTEE:

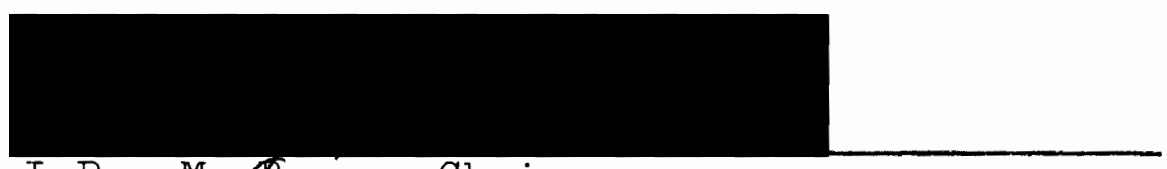

LaRay M. OBarna, Chairman
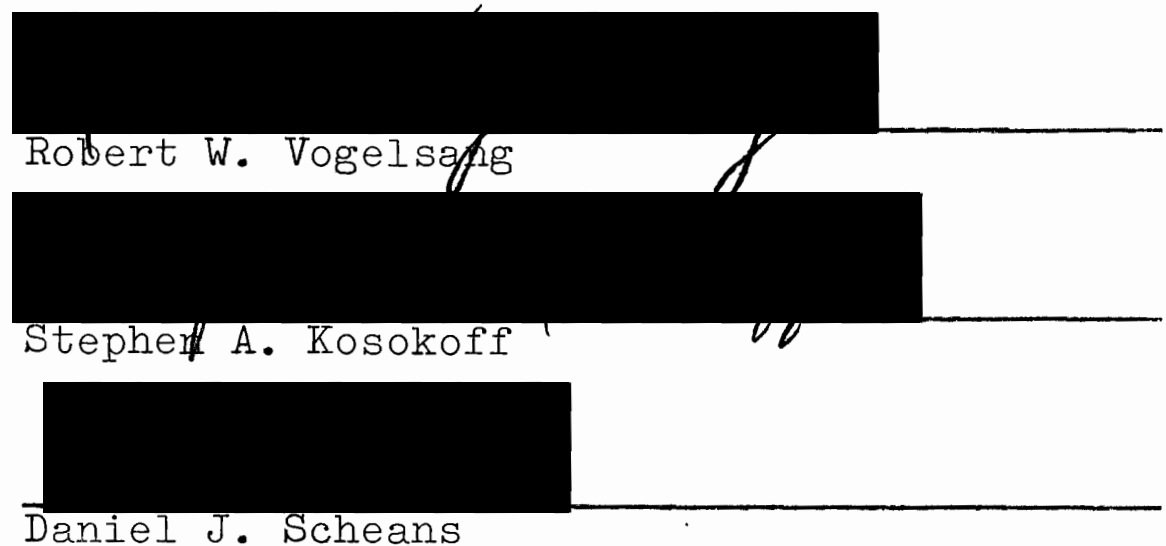

This study is an empirical analysis of communication styles in Japan and the United States. In particular, the study deals with communication styles in Japanese and American television commercials as a reflection of human communication styles in the two countries.

In a review of the literature, studies describing the characteristics of human communication styles in Japan and 
the United States are surveyed. Lack of verbalization, high value placed on silence, and importance of facial expression are identified as major characteristics of (indirect) communication style in Japan. An emphasis on verbalization, especially with regard to being specific, and prevalence of dichotomous expressions are identified as major characteristics of (direct) communication style in the United States.

In order to prove that these characteristics of communication styles are reflected in Japanese and American commercials, five components of communication style are selected for analysis: (I) character (who is communicating to whom), (2) content (choice of symbolic behavior to convey the meaning), (3) ratio of verbal to nonverbal behavior, (4) time span between verbal and nonverbal behavior, and (5) tone of voice.

Next, six research hypotheses are constructed based upon the following theoretical hypothesis: the communication style of American television commercials is more direct than the communication style of Japanese commercials. The six research hypotheses are structured from the five components of communication style indicated above. The six are: (1) there will be higher ratio of commercials using the character of a straight presenter (direct) as opposed to the character of an entertainer (indirect) in the United States than in Japan, (2) there will be a higher 
ratio of commercials which present product information explicitly (direct) as opposed to implying product information through verbal or nonverbal means (indirect) in the United States than in Japan, (3) there will be a greater proportion of verbal (direct) to nonverbal (indirect) presentation in the United States than in Japan, (4) the time span between initial visual display of the product and the verbal announcement of the product will be shorter (more direct) in the United States than in Japan, (5) there will be a higher ratio of commercials using a serious (direct) rather than a humorous (indirect) tone of voice in the United States than in Japan, and (6) there will be fewer commercials that are accompanied by music (more direct) in the United States than in Japan.

The major conclusion reached is that the communication styles revealed in their television commercials are generally indirect in Japan and direct in the United States. Typically, in a Japanese commercial an advertised product is presented less verbally than in an American commercial. Accompanied by music, the Japanese television advertisement will begin with a close-up of the product followed by an announcement of the product's name. The explicitness of the content is low; messages are usually implied and hinted. On the other hand, the typical product in an American commercial is presented by explicit verbal description, simultaneous with a close-up of the product and the announcement of the product name, without music accompaniment. 
A COMPARATIVE STUDY OF COMMUNICATION STYLE IN JAPAN AND THE UNITED STATES AS REVEALED THROUGH CONTENT ANALYSIS OF TELEVISION COMMERCIALS

NORIKO HURUSE

A thesis submitted in partial fulfillment of the requirements for the degree of

\author{
MASTER OF ARTS \\ in \\ SPEECH COMMUNICATION
}

Portland State University

1978 
TO THE OFFICE OF GRADUATE STUDIES AND RESEARCH:

The members of the Committee approve the thesis of Noriko Huruse presented July 6, 1978.

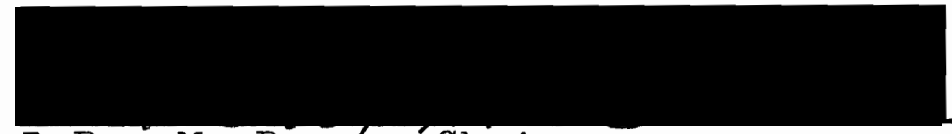

LaRay M.·Barga, Chairman

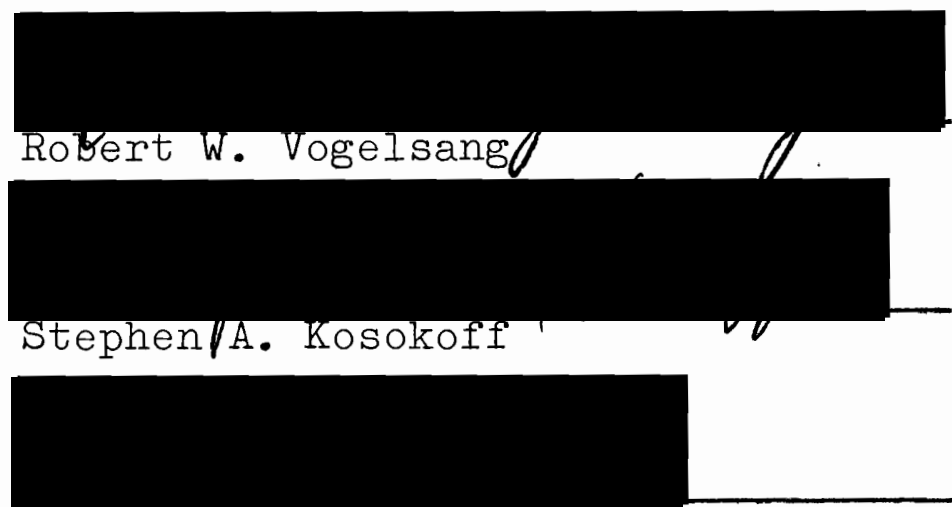

Daniel J. Scheans

APPROVED :

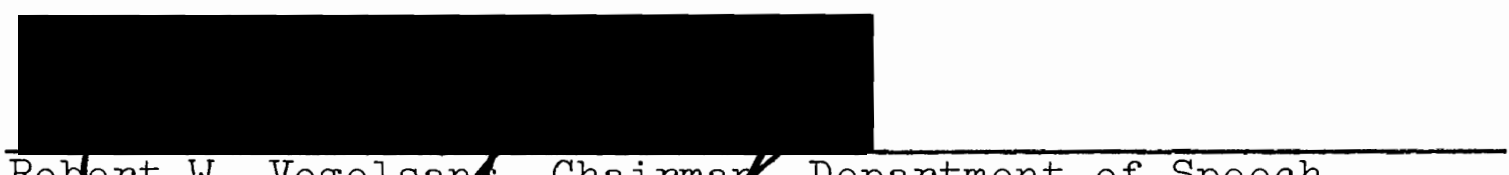
Roblert $W$. Vogelsans, Chairmay, Department of Speech
Communication

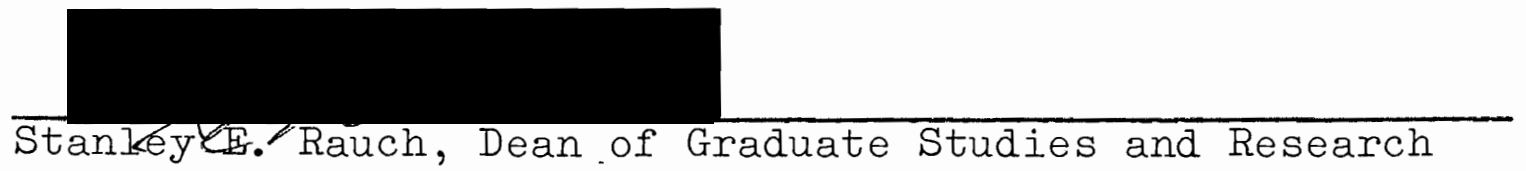




\section{ACKNOWLEDGMENTS}

At this time, I would like to express my appreciation and gratitude to those who made it possible for me to complete this thesis.

First, I would like to thank my family, my father, mother, and sister, who have provided love and care across the Pacific Ocean. They have always encouraged my education in the United States with great understanding.

I am also thankful to all my friends, Reiko, Chris, Julie, Eiko, Hiro, and Ann who always had time to listen to me and share their knowledge and experience related to this study. Yoshio, who has always provided love and encouragement, deserves my gratitude. Also, Kimi and Duane deserve special thanks for sharing their time and effort in editing and typing with friendship and love.

For the completion of the thesis, my committee deșerves much gratitude. Mrs. Barna, my adviser for seven years, devoted her time, effort, and knowledge. Without her guidance and love, I would not have completed my studies at Portland State University. Dr. Kosokoff provided penetrating advice and criticism. Dr. Scheans also provided many helpful ideas and suggestions. I am also grateful for the enthusiasm, patience, and teaching of Dr. Vogelsang, my adviser during Mrs. Barna's sabbatical, and a member of 
the committee. Dr. Grove, although not a committee member, helped to develop the basic shape of the study. Special appreciation is given to Dr. Karr from the Department of Psychology for his contributions to the data analysis.

There are many people who deserve my special gratitude. Mr. Maeda, the chairman of International Relations at Mainichi Broadcasting System, Inc., sent me a videotape of television commercials from Japan and in this way helped make my dream come true. Mr. Gamo, Vice President and General Manager of Dentsu Corporation of America kindly permitted an interview during my visit to the 1977 Summer Symposium at the University of Southern California. Dr. Katz, who is a professor at Hebrew University and was a guest of honor at the summer symposium, shared his knowledge with warm encouragement. Acknowledgments also go to Mr. Kawashima of Dentsu Advertising Ltd., in Tokyo; Mr. Nukita of Channel 12 in Tokyo; Mr. Chamber of KGW in Portland, and to Dr. Maurer and Dr. Enneking at Portland State for their contributions to the study.

Lastly I am grateful to Mr. Walker, Mr. Kimball, Ms. Wells, and other staff members of the PSU TV Service for their help in videotaping television commercials and adjusting the speech cart. In typing the thesis Mrs. Vogelsang has provided more than professionalism and experience. I am thankful to all of these people. God bless them all. 
TABIE OF CONTENTS

PAGE

ACKNOWLEDGMENTS

IIST OF TABLES

CHAPTER

I INTRODUCTION • • • • • • • . • • • • 1

Overview . . . . . . . . . . . 1

Purpose .... . . . . . . . 4

Justification of Study . . . . . . 5

II SURVEY OF COMMUNICATION STYLE . . . . . 10

Definitions of Communication Style . . 10

Communication Style in Japan . . . . 11

Communication Style in the

United States . . . . . . . 26

III BASIS FOR THE STUDY • . • . • . • . . 39

Basic Assumptions . . . . . . . 39

Components of Communication Style • • 43

IV HYPOTHESES AND RATIONALES . • . . . . 50

Theoretical Hypothesis . . . . . 50

Research Hypotheses and Rationales . . 50

V METHODS AND PROCEDURES • • • • • • • . 54

Population and Sampling . . . . . 54

Data Analysis . . . . . . . 61 
VI RESUITS AND DISCUSSION • . • . • . • 65

Results ........... 65

Interpretation of Findings . . . . 78

Suggestions for Future Research . • . 84

VII CONCLUSION . . . . . . . . . . 87

BIBLIOGRAPHY • • . . . . . . . . . . 91

APPEND IX

A Directions for Judges, and Scoring Sheet . . 97

B Iist of Japanese and American Television

Commercials ............ 102

C Modification of Scott's $\pi$....... 107 


\section{IIST OF TABLES}

TABLE

PAGE

I Observed Frequency of Different Character of Actors . . . . . . . . . .

II Observed Frequency for Categories

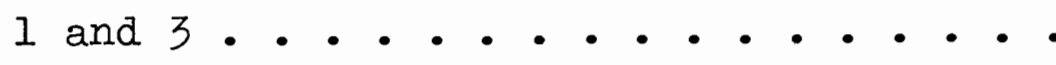

III Observed Frequency for Explicitness of

Content . . . . . . . . . . .

IV Summary of Student's $t$ Results for the

Proportion of Verbal Presentation

to Nonverbal Presentation . . . . .

$V$ Median Test: Form for Differences in

Time $\operatorname{Span} \cdot$. . . . . . . . 71

VI Observed Frequency of Difference in the

Vocalized Sound . . . . . . . .

VII: Observed Frequency of Difference in the

Extent of Music Used . . . . . . . 74

VIII Observed Frequency of Assignments by

Judges II and III of Japanese

Television Commercials . . . . . . .

IX Inter-rater Reliabilities in Categorizing

Television Commercials . . . . . 76 
$\mathrm{X}$ Inter-rater Reliabilities in Coding

Data for Testing Hypotheses

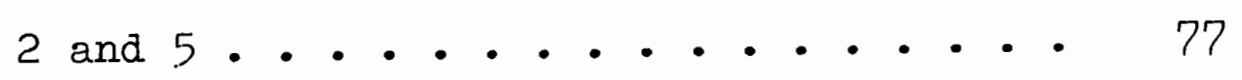

XI Contingency Table for Judge A and B . . . 108 


\section{CHAPTER I \\ INTRODUCTION}

\section{OVERVIEW}

On September 15, 1977, the Port of Portland accepted a bid of $\$ 17,520,000$ for construction of the new 982-foot drydock by the Ishikawajima Harima Heavy Industries Co., Itd., (IHI) of Tokỹo. The matter had received a great deal of publicity because the company's bid was $\$ 2,874,000$ lower than the next lowest bid. Upon inquiry of how IHI was able to bid so much lower than any other firm, the sales manager answered that they just sharpened their pencils so much they almost broke them. ${ }^{1}$

There was no specific interpretation of his statement in the newspaper; however, someone who knew the Japanese way of speaking would understand the metaphor. The expression of sharpening a pencil refers both to curtailing expenses and to the process of decision making. Also, the expression of "almost broke them" implies that there was very little profit to be made through this contact. Metaphorical and indirect expressions are often used by Japanese. Reischauer explains that:

Japanese have always seemed to lean more toward subtlety and sensitivity than to clarity of analysis, 
to intuition rather than reason, . . Aside from the flat factual statements of newspaper reporting, they value in their literature, not clear analysis, but artistic suggestiveness and inference.2

In contrast to the IHI sales manager, Lloyd Anderson, the Port's executive director, made no ambiguous statements. His statements were always supported by facts and clear figures. The contrast between the two communication styles in this instance is vivid.

This local affair suggests the possibility that problems in intercultural encounters can be caused by differences in communication styles. No doubt some readers speculated on the meaning of the statement made by the IHI sales manager. Confusion over the meaning of the metaphor was only half the problem. The other half consisted of why the Japanese businessman did not answer the question directly like it was asked. Fortunately, there is no crucial problem in this instance; rather, the officials of the Port of Portland, reporters, and most other Portland citizens reacted favorably to his statement. Not only his statement, however, but also his behavior through the entire press conference probably reinforced the stereotype of Japanese as being, "inscrutable."

The act of unconsciously interpreting another's communication in terms of one's own communication style is common. It is impossible to use the other's cultural norms and social contexts when they are not known to the 
listener. In intercultural communication people are often not only baffled by meanings but Iikely to evaluate negatively what they do not understand. The application of a stereotype helps "make sense" out of the incident. But generalizations or stereotypes are often stumbling blocks because they interfere with the objective viewing of stimuli. 3 It is even more difficult to "correctly interpret meanings conveyed through a different communication style when also influenced by stereotypes.

Although culture contrasts of language and various aspects of nonverbal communication have appeared in the literature, there are very few studies on communication style itself and its effects on intercultural communication. It seems, therefore, that a systematic study in the area is needed. The present study hopes to accomplish this end by, first, discussing previous studies of Japanese and American communication styles and definitions of communication style in general. In doing this an attempt was made to avoid preconceptions and stereotypes. Next, components of communication style that are particularly relevant in intercultural settings are developę. Finally, an empirical study of the differences in Japanese and American communication'stylès, as revealed in their television commercials, is conducted using these components of communication style as the base. 


\section{PURPOSE}

The major purpose of this study is to compare and contrast Japanese and American communication styles as revealed in the television commercials of the two countries. It will be determined whether the respective communication. styles used are direct or indirect.

In order to investigate the features of the communication styles in both countries, five components were selected. These include (1) character of actor or presenter, (2) content (choice of symbolic behavior to convey the meaning), (3) ratio of verbal to nonverbal behavior, (4) time span between initial verbal and initial nonverbal behavior, and (5) tone of voice. These components were developed into six questions for testing as follows:

1. Was a product introduced directly by a straight presenter or indirectly by an entertainer?

2. Was a product introduced directly by explicit product information or indirectly by implication of such information?

3. Was a product introduced by a predominantly verbal presentation or indirectly by a predominantly nonverbal presentation?

4. Was a product presented directly by relatively short span between the initial visual display of the product and the verbal announcement of the product or indirectly 
by comparatively longer time span between them?

5. Was a product presented directly by serious tone or indirectly by humorous tone?

6. Was a product presented with musical accompaniment (indirect) or without musical accompaniment (direct)?

JUSTIFICATION OF STUDY

It is widely recognized that in the past three decades Japan and the United States have become increasingly interdependent. Bilateral trade in particular has grown enormously, increasing fourfold in the ten year period from 1963 to 1972.4 However, this growth in trade has not been accompanied by a corresponding growth in the mutual understanding between Japan and the United States and the rest of the world. The reality is that "misunderstandings, misinterpretation of motives, and mutual lack of understanding are growing more common." 5 A major factor in this lack of understanding is the problem of differences in communication styles. A principle aim of the present study is to narrow the existing communication gap between Japan and the United States by identifying the precise nature and extent of these differences.

Various studies of the communication styles of different cultures have been made from historical, anthropological, and psychological points of view. Also, many valuable articles have been written based upon personal 
experiences. As such, the conclusions reached by these studies are often subjective and evaluative. The empirical study of communication style would overcome the problem of subjectivity. However, because of the difficulty of the objective observation of communication style in a laboratory setting, up to now few such studies have been attempted.

This thesis takes the view that various human communication styles can be empirically studied through analysis of carefully selected samples of the television media. This opposes Katz's theory that there is crosscultural homogeneity of television programs, ${ }^{6}$ but it is supported by Bowman's view that subtle cultural differences in television programs are evident in patterns of deference from children to adults.?

Also, Katz acknowledges that there may be some subtle cultural differences in the television media even though his recent research supports the cross-cultural homogeneity of television programs. ${ }^{8}$ His statement is that there may be no or few cultural differences between the European mass-mediated cultures. This is because European countries are in near proximity and share similar cultural backgrounds. It is the opinion of the author that the crosscultural homogeneity of the television media does not exist between Japanese and American television programs. Although they share similar economic and political systems, 
clear differences in racial composition, value orientations, and other features distinguish Japanese and American cultures. It is also important that more than 90 percent of television programs broadcast in each country are produced domestically. 9 Therefore, there is a higher possibility of cultural reflections in Japanese and American television programs than in other countries.

In most studies of communication style, verbal and nonverbal behaviors have been observed separately. However, Pike notes that since language behavior and nonlanguage behavior are fused in single events, it is important to analyze the two behaviors as a single unit and also to analyze the correlation between them. 10 Because of differences in the relative importance of verbal and nonverbal behavior in each country, this is particularly true in the study of communication styles in Japan and the United States. In Japanese culture, nonverbal behavior is perceived to be as important, if not more important, than in the United States where nonverbal behavior is not emphasized. These contrasting values placed by Japanese and American cultures on verbal and nonverbal behaviors are observable only when the two behaviors are analyzed as a single event, and their correlation studied.

Throughout this study, the possibilities for using mass-mediated culture for the empirical study of human behavior, and the possibilities for using the humanities 
and social science for the comparative study of Japanese and American advertising methods are demonstrated.

Secondly, communication styles in Japan and the United States are studied systematically by combining behavioral science with humanistic psychology. 
Chapter 1--Notes

I The Oregonian, 16 September 1977, Sec. A, p. 1 .

$2_{\text {Edwin }} 0$. Reischauer, The Japanese (Cambridge: Harvard University Press, The Belknap Press, 1977), p. 227.

${ }^{3}$ IaRay Barna, "Intercultural Communication Stumbling Blocks," in Intercultural Communication: A Reader, 2nd ed., edited by Larry A. Samovar and Richard E. Porter (Belmont, California: Wadsworth Publishing Company, Inc., 1976), p. 294.

${ }^{4}$ Tadao Umesao, "Escape from Cultural Isolation," the wheel extended, IV (Winter 1974), p. 8.

5 Ibid., p. 10 .

${ }^{6}$ Interview with Elihu Katz, Professor, Hebrew University, at The. Annenberg School of Communications at the University of Southern California, August 9, 1977.

7 Ibid.

${ }^{8}$ Elihu Katz, Social Research on Broadcasting: Proposals for Further Development (Publicity and 'Information Department, British Broadcasting Corporation, 1977).

9 UNESCO, Reports and Papers on Mass Communication No. 70, Television Traffic--A One-Way Street? A Survey and Analysis of the International Flow of Television Programme Material (Kaarle Nordenstreng and Tapio Varis, 1974), P. 13-14.

10 Kenneth L. Pike, Language in Relation to a Unified Theory of the Structure of Human Behavior, 2nd ed. (The Hague, Netherlands: Mouton \& Co., Publishers, 1967), p. 26: 


\section{CHAPTER II}

\section{SURVEY OF COMMUNICATION STYLE}

\section{DEFINITIONS OF COMMUNICATION STYLE}

Until recently, the study of public speaking was the strong emphasis in the field of speech communication, and included an interest in style. Style was defined in that context and included such phrases as "style is the dress of thoughts," 1 and ". . that factor in the dynamics of speaking which results from the selection and management of language." 2

The classical definition of style was set forth by Sarett and Foster:

Style is a reflection of the person himself, as is ethos, but of his temperament as well as his character--of how he thinks and feels, as well as what he thinks and feels; . . Oral style is the total order, movement, and expression of an individual's ideas and feelings as revealed in the language of speech. 3

Most recently, style had been defined in terms of total communicative behavior. For example, in 1974, Norton, Pettegrew, and Land introduced communicator style as one part of communicative behavior.with the following statement:

Two basic communicative behaviors simultaneously influence communication processes: (1) what is said, and (2) how it is transmitted. The former activity marks the lateral, the denotative, the 
content. The latter activity characterizes the vehicle, the punctuation, the connotative, the style of communication. 4

Similarly, in his study of perception and communication style, Miller defines communication style as "the way' in which one communicates." 5

In the past, the qualities of effective style were thought to include clarity, correctness, concreteness, vividness, appropriateness, ${ }^{6}$ or clarity, correctness, appropriateness, emphasis, unity, and coherence.?

More recently, Norton and others identified five separate components of communication style, dominance, animation, relaxation, openness, and attentiveness--based upon the correlation between communication style and attraction during interpersonal interaction. 8

In this study communication style is defined as one's total communicative behavior. This includes not only verbal and nonverbal behavior, but also the socialcultural context of such behavior.

\section{COMMUNICATION STYLE IN JAPAN}

\section{Cultural Background}

Archeological evidence indicates that no large waves of immigrants have come to Japan after 500 A.D. 9 This long-term racial homogeneity undoubtedly led to a sharing of values, beliefs, attitudes, and life-styles, and this, in turn, led to the development of a singular style. 
Buddhism placed great value on silence and the communication of ideas and feelings nonverbally. 10 Sabi, the meditative influence of Zen Buddhism, represented that quality of beauty obtained through refined simplicity, restraint, and suggestion. ${ }^{11}$ Moreover, Japanese geographical isolation and the high density of its population created a need for social harmony and conformity with nature and among themselves.

Ecological conditions and the permeation of Buddhism into Japanese culture developed a unique human relationship in Japanese society. The Japanese system of hierarchy is well known throughout the world. Reischauer claims that no major people in the world put greater emphasis on hierarchy than do the Japanese. ${ }^{12}$ The most fundamental hierarchical: order in Japan is age and sex. The use of the honorific and the distinction between women's and men's talk illustrates the hierarchical social role in Japan.

Another unique characteristic of Japanese human relationships mentioned in the literature is empathic interdependence in interpersonal communication, especially in a one-to-one relationship. The early work of Nakane explains this phenomenon as a feeling of "one-ness."13 Later, she develops this "one-ness" as the concept of renzoku, ${ }^{14}$ which literally means continuity of succession. Renzoku can be defined as the interdependence of people when they establish a certain relationship such as 
friendship. When two people establish such a relationship, they lose a certain degree of individuality, and gain. interdependence. This phenomenon is also observed by Takeo Doi who labels it as amae. ${ }^{15}$ He explains this interdependency in Japanese human relationships from a psycholinguistic point of view.

To better explain this interdependence in Japanese human relationships the concept of uchi and soto is cited as an indispensable key factor. Uchi literally means "inside," and according to Nakane, may mean the institution as a whole, or it may mean the department or section to which the speaker belongs. ${ }^{16}$ The opposite definition applies to soto. If $A$ and $B$ 's interpersonal relationship is classified as being on a soto level (literally translated as "outside"), their conversation is more phatic, ritualistic, and formal. Once their relationship moves from soto to uchi (renzoku), then higher interdependence is. maintained with each other (amae).

Barnlund analyzes Japanese and American interpersonal communication through the concept of public and private self. He explains that "private self" is made up of aspects of the person that are potentially communicable, but are not often or not usually shared with others. 17 . The "public self" on the other hand, is composed of aspects of the person that are readily available and easily shared with others. 18 Barnlund proves that the Japanese public self is smaller than the American public self. 
The presence of two levels in Japanese private self can be explained in terms of concept of uchi and soto. Nakane explains uchi's feature as:

- . with his social environment so limited, the scope of an individual's relations within his own group becomes proportionately more intensified. Obligations and expectations among the members of the group are exacting; members of a group know each other exceedingly well--one's family life, love affairs, even the limits of one's capacity for cocktails are intimately known to the others. 19

Uchi also means family. The family system, or kinship is another key to understanding human relationship in Japan. The primary unit of social organization in Japan is "ie" or household. However, "ie" is conceptualized "not only as a contemporary household but also as all familial household from past to future, including dead members." 20 The fact that Japanese usually identify each other by family name (people recognize a person not as an individual but as a member of a certain family) illustrates the importance of "ie."

In summary, Japanese society is highly group oriented. This characteristic has probably developed as a result of racial homogeneity, the influence of Buddhism, interdependence in human relationships, and family structure. All these have contributed to the development of a unique communication style. 
Verbal Characteristics of

Japanese Communication

Style

Many studies indicate a lack of verbal rhetoric, 21 which is sometimes called the Japanese unarticulated attitude. 22 These illustrate a tendency for there to be implied and hidden messages in Japanese verbal expression, and the importance of nonverbal expression.

The tendency toward minimum use of language in Japanese culture is a different communication style than in American culture. In the United States, language is considered highly important, partly because it is an instrument of debate or argumentation. 23 For example, political speeches are used to persuade through an appeal to information, reason, and emotions. Americans constantly analyze the speeches given by the president and other important figures. It can safely be said that a person has a better chance of being elected to public office in the United States if he is a good speaker. 24

On the other hand, Condon points out that in Japan, something said in public is less important because the expressing of one's inner thoughts is restrained; it is important not to offend anyone. Everything said in public is, as it were, "mealymouthed."25 Similarly, people often hesitate to debate or argue, because verbalization for the purpose of persuading others is often interpreted as being offensive. According to Kunihiro, "in Japanese society, 
use of words became a sort of ritual, not often to be taken at face value." 26

Speculation can be made about this particular characteristic of verbal expression in communication style by studying the traditional literary art forms of Japan, such as haiku, tanka, and so on. Haiku, more familiar than tanka in the United States, is the shortest form in poetry. Tanka is the original form of haiku, and has been loved by the Japanese people for more than 1500 years. Whereas haiku consists of 17 syllables, tanka is arranged in five verse with 5-7-5-7-7 syllables, respectively. In this poetic form, phase of immutable nature is depicted, with a "surge of emotion evolved by a key word."

Haru tateba kiyuru kori no nokori naku

Kimi ga kokoro mo Ware ni tokenan
When spring comes the melting ice leaves no trace; Would that your heart too
melted thus toward me.2?

Edwin 0. Reischauer, a former United States ambassador to Japan explains:

If much is to be expressed, it must be through suggestion--the creation in the mind's eyes of a vivid scene by a brief mention of its key detail and the stimulation of an emotional response by a mere symbol or the juxtaposition of two contrasting images. The typical Japanese poem tersely conjures up a picture, usually a beautiful scene from nature, and then by a deft turn transforms the visual impression into a surge of emotion. 28

By the Heian period, 800 A.D., tanka was developed into a kind of debate format, called utaawase. This was different from debate in western civilization. People 
competed by putting predetermined topics into poetic form, usually an emotion or reference to nature, and in transmitting feeling about their opponents. 29 The utaawase was mainly conducted by the imperial court; however, it became popular among common people by the end of the Heian period. Poetry which requires such a restrained conformity of form was regarded as one of the highest manners of conveying ideas and thoughts. Putting people's thoughts and emotions into poetry was beloved by Japanese until World War II. 30 Haiku and tanka are still popular today. This attitude has intensified the tendency not to debate or argue by verbal expression alone, but instead, to develop the implied message within a limited expression.

Kunihiro analyzes the process of Japanese verbal interaction thus:

Rather than an expression of one's own will or thoughts, language had been a way of casually throwing the other guy a ball in order to get a reaction from him on which to base one's next action. 31

The polite apology, which can be found in formal Japanese conversation, reflects this phenomenon. To illustrate, "Musakurushii tokoroe yoku irasshaimashita," is literally translated as "Welcome to such a squalid place." By this ritualistic expression, a host attempts to elicit a compliment regarding his house.

The implied message contained within the verbal expression is a distinct feature of the indirect 
communication style in Japan. The decoder or listener is expected to fill in the unexpressed ideas and emotions within the verbal message through his own experience. - In this way, the encoder in transmitting his ideas, must be empathic toward the decoder.

Nonverbal Characteristics in Japanese Communication Style

Before discussing the aspect of nonverbal behavior in Japanese as part of their indirect communication style, the control of emotions, especially in public, is a subject which should be mentioned. On this subject, Nakane reports that the Japanese are as emotional as the Italians, but that the emotions of the Japanese are directed toward or against others, whereas the emotions of an Italian may only reflect his feelings at the time and have no relationship to others. What is more, Japanese go out of their way to conceal their sentiments. 32

Even though famous for controlling their emotions, the Japanese are said to be a "right hemispheric" and emotional people. This contradiction is referred to by Reischauer as "a contradiction between the basic emotional drive toward self-expression and the counterbalancing social force of conformity." 33 He explains further that:

The dynamic balance between these two forces is as fundamental to our civilization as to that of Japan, but the degree of tension created between these two forces seems in some respects to be greater in Japan. Their point of balance seems to us decidedly off-center. The emotional drive toward self- 
expression appears to be, if anything, greater among the Japanese than with us, but at the same time the Japanese have developed a counterforce of social conformity which is far stronger than anything with which we are familiar. 34

In a culture which curbs free emotional expression, subtle nonverbal expression plays an important role in commucation style. Birdwhistell estimates that more than 65 percent of the meaning of a situation in Japanese society is transmitted by nonverbal behavior. 35 This percentage is much higher than is true of most other countries. Many studies are available dealing with the nonverbal aspects of Japanese communication style; including the use of the bow, the control of gestures during interpersonal interaction, the shortness of eye contact, facial expressions, the use of silence, and the like. Among these aspects, facial expression is one of the most difficult, although interesting, to interpret. Of first importance is that Japanese facial expressions reflect a cultural feature of social conformity in the expression of emotion. As if "Noh" masks were worn in public, the facial expressions of the Japanese are controlled and reserved, especially negative ones such as in expressing shock or upset at unexpected bad news. 36 In other words, smiling and laughing do not always reflect happiness and joyfulness. They may frequently be used to conceal displeasure, anger, or sorrow. 37

Morsbach mentions two Japanese ideographs for "face" to explain the meaning of facial expressions in Japanese 
social interaction. An ideograph pronounced kao means simply "face," whereas another ideograph pronounced men has the meaning of both "face" and "mask." 38 This illustrates that there are two different levels in Japanese facial.

expressions. The two levels are linked to the concepts of uchi (inside) and soto (outside). Human interaction at the uchi level consists of uninhibited facial expression. The communication style for expressing emotion at the uchi level is more direct and explicit. At this level people are not as reserved in their "face" as they are at the soto level. In public, however, facial expression at the soto level undergoes a subtle change to conform to the socially accepted reserved mask.

Reading of facial expression is an important and necessary strategy in human interaction in Japan. According to Kunihiro, the actual emotion hidden behind a mask of smiling or laughing has to be understood independent of verbal interaction. 39 In this case, highiy empathic communication is demanded. Kunihiro points to this phenomenon in the case of decision making in modern Japanese companies: In actuality, the process of a meeting has no bearing at all on decision making. The chief might never utter a word yet everyone knows the proposal he favors and the meeting will conclude with unanimous agreement on it. 40

Thus it is clear that, whether it is freely expressed emotion in the face, or emotion concealed by the mask of conformity, facial expression reflects the indirect method of communication. 
Japanese cultural attachment to "face" or facial expression may be observed in Japanese theater. In Kabuki, the heavily expressive and exaggerated make-up worn by actors is used to present terrible nonhuman facial expressions, but there is a simple and plain make-up for humans. Ernst explains the relationship between the make-up and facial expressions as follows:

The detachment of the actor from the role is further marked in his make-up. The face of the actor onstage is a compromise between the human face and the mask. The mask-like quality is created both by the make-up and by the propensity of the actor to reserve facial expression for only the most significant moments. 71

It follows that it is possible to speculate that the importance of make-up and facial expression in Kabuki theater reflects the two levels of facial expression in Japanese culture represented by uchi and soto.

Noh, the classical Iyric dance-drama, is another famous theater in Japanese tradition. In this theater, the actors wear masks that are capable of changes in facial expression. Morsbach explains that some masks worn by the main performer in Noh plays can convey various nonverbal shades of emotion to the audience, depending on the angle at which they are tilted in relation to the lighting. 42 These subtle changes of facial expression achieved by slightly changing the reflection of light show the importance of facial expression in Japanese culture. 
The art form of Bunraku puppets also attach great importance to facial expression. The mouth, eyes, and eyebrows are all movable. Scott notes, "the eyes of a puppet can open and close, turn left and right, or squint, and that these movements may be done singly, or in conjunction with moving the eyebrows up and down, or opening and closing the mouth. "43 Nowhere in the world is there a puppet as capable of moving as many parts of the face to express emotion as in Japan.

These Japanese representative theaters demonstrate the importance of facial expression as a means of expressing emotion on the stage. By extension, they also suggest that facial expression is an aspect of one's social role in Japanese human interaction.

Silence is another important aspect of Japanese non-... verbal communication. Silence is literally translated as chinmoku. Other words, such as $\underline{\underline{m u}}$ and ma have the meaning of the "aesthtics of silence. "44

A good example of the effective use of silence is the following. In the fall of 1970, the annual exhibit of flower arrangements by Sofu Teshigawara, chairman of the Sogetsu flower arrangement school was titled "chinmoku." He arranged a large pine tree and large bunch of white camellia in the center of the exhibition room, with a small bunch of flaming crimson camellia behind the white camellia. Sofu's message was very clear to those who were aware of a 
management problem at the school. In early 1970 it was publicly exposed that there was evasion of taxes by the school. Although he may not have been personally responsible, as head of the school sofu accepted formal responsibility for the scandal. The white camellia indicated his controlled silence, while the red camellia conveyed his blood boiled with anger. He made no excuse publicly and remained silent, because that was the most respectable way of showing that he personally had nothing to do with the evasion of taxes. 45

As previously mentioned, the high value attached to. silence in Japanese culture can be traced to the influence of Zen Buddhism. Most important in this connection is the concept of $\mathrm{mu}$, which can be translated as nothingness or no-mindedness. According to this Zen concept

- man is capable of arriving at the highest level of contemplative being only when he makes no attempt at verbalization and discounts ofal expression as the height of superficiality. 46

Ma, it is important to point out, represents not only emptiness space-wise, but also silence time-wise. It often refers to silence in human interaction. In this sense, ma means the silence between interactions. In Japanese informal conversation, the correlation between verbal and nonverbal expressions is almost the exact opposite of that in the United States. There is a longer pause between a person's idea and the other's response. The Japanese tend to leave out their conclusion through silence and to let 
others fill in the conclusion. Silence is another aspect of the Japanese indirect communication style.

Thought Pattern in Japanese

Communication Style

In an investigation of communication style in Japan, thought patterns must be included. Language often reflects one's thought pattern, and thought pattern is often a part of reasoning or rhetorical functioning. As an example, American professors often complain that papers written by Japanese students jump from one idea to another, often without the development or support of statements. This feature of Japanese student work is related to Kurita's view of Oriental languages as "terminal languages, "47 i.e., languages that skip "process" and go directly to a conclusion. In this regard Kunihiro observes that statements by Japanese fall into two broad categories:

(1) "Dot-type" statements refer to the presentation of one item after another in a highly anecdotal or episodic vein, in which conclusions are seldom articulated, and (2)

The second type is observed largely in the statements made by people who may have been influenced by continental (Chinese) philosophers. These people tend to think deductively, presenting maxims and axioms as they are, often unaccompanied by actual data. 48

Similarly, Yoshihiro Kobayashi explains the process of presenting ideas in Japanese in terms of the concept of nemawashi (literally, digging around the roots of a tree), which means to maneuver behind the scenes. ${ }^{49}$ He points to 
two features of Japanese reasoning style that contrast with the French style. One is that the Japanese talk around the: periphery of a subject first, and come to the conclusion last, whereas the reverse is true of the French style. 50 The other is that individual interest and motivation are often mentioned as a matter of course in the Japanese reasoning style. This reflects the speaker's character to some degree, and can serve as data for evaluation of the speaker. 51 This is also not true of the French style. All in all, the review of the literature on Japan reveals that the communication style of the Japanese is thought to be predominantly indirect, i.e., rather than being explicitly stated, the message is often implied, suggested, or hinted. Verbalization is not as important in conveying meaning in Japanese communication style as is regarding other's nonverbal cues; it is mostly used as rịtual. This unarticulated attitude is often reflected in such Japanese sayings as "eyes are as eloquent as lips." Nonverbal cues often reflect and fulfill a message left out of a verbal expression. This is because the Japanese often hesitate to express their emotions directly owing to their great regard for modesty. 
COMIUNICATION STYLE IN THE UNITED STATES

\section{Cultural Background}

Exaggeration is often thought by the Japanese to bet the most noticeable feature of colloquial American speech and writing. Also "open," "frank," and "talkative" are terms commonly used by the Japanese to describe the typical American. 52 These words do not merely describe the Japaniese stereotype of Americans, rather, they reflect aspects of American communication style as observed through a Japanese frame of reference.

An historical perspective on American communication style is provided by the following passage.

And here is the United States, an immense country sparsely settled, richly endowed, tied through waves of immigrants to the heritage of Europe, yet forced to subdue nature and find fresh solution to the problems of survival. 53

This is Barnlund's view of the American pioneer settlements, which developed a unique communication style. It has been said that the origins of the direct communication style can be traced to the early immigrants' instinct for survival. In other words, it was necessary for immigrants to express their thoughts explicitly and clearly in order to survive in a new and often hostile land. Exact and clear expression. was the best communication strategy to avoid any misunderstanding among peoples from different cultures.

Unlike the Japanese who could not evade social conformity because of their racial homogeneity and high density 
population, American pioneers were separated from each other by distance and cultural diversity. Thus, a strong social conformity did not develop. Rather, as Peter von Zahns described with the expression "people without forms," individualism emerged as a dominent feature of society. 54 Andrew M. Greeley illustrates this facet of American culture in the following way: ". . to this... question [why can't they be like us], there can be but one satisfactory answer. Because they don't want to be and in the United States of America they don't have to be. "55 The direct communication style was an adaptation to a culture without conformity which necessitated the clear and exact expression of one's inner thoughts and feelings. Proof of the need and desire to express their inner thoughts and feelings are statements that appear as to why people came to the new continent. The spirit of the founding fathers is also clearly seen in the First Amendment to the Constitution of the United States:

Congress shall make no law respecting on establishment of religion, or prohibiting the free exercise thereof; or abridging the freedom of speech, or of the press; or the right of people peaceably to assemble, and to petition the Government for a redress of grievances. 56

Sibley explains the American doctrine of freedom of thought and speech in terms of four major elements:
(I) an accent on the individual;
(2) a strong "natural law" tradition which denies any necessary equation between collective decisions and the ethically right; (3) a distrust 
of external constraint in matters of belief; and, (4) an emphasis on contingency in human affairs, both individually and collectively. 57

In summary, the strong desire for freedom of expression combined with the heterogeneity of American culture were major influences in the development of the direct communication style in the United States.

\section{Verbal Characteristics of}

American Communication

Style

One of the distinct features of the verbal aspect of American communication style is its specificity. Sharpening the focus, narrowing, and delimiting the field of observation are important in writing any kind of paper. Stewart explains the American attitude toward language as follows:

The Americans' use of language tends to be specific to a context and frequently reflects general cultural assumptions and values. The foreigner is puzzled by the vagueness and ambiguity until he has mastered both the context and the culture. 58

This aspect of being specific is reflected in human behavior. For example, the colloquial phrase "I mean" is frequently used to introduce a modification or clarification of a former statement. 59 There is no equivalent literal translation in the Japanese language which has the same meaning as the phrase "I mean." This is because avoiding the specific and not going one step further than anybody else is highly important in Japanese society. 
This same contrast in styles is seen in American and Japanese greeting behavior. Krivonos and Knapp studied greeting behavior in their study of the correlation between verbal and nonverbal behavior. 60 The American greeting pattern observed among people who were acquainted was much more specific and verbally oriented than the pattern among Japanese who were acquainted. In particular, they discovered eight sequential stages in American greeting behavior. These included three nonverbal and five verbal stages. Among the latter were verbal salute (such as "Hi"), external reference ("Did you do your homework?"), and personal inquiry ("What's happening?"). Each of the eight stages had a different function within the context of indicating the maintenance of a relationship. In contrast, in Japan ritual greeting behavior was found to be much more vague and ambiguous. The verbal salute was often replaced by a personal inquiry, or even by an external reference. As an example, the question "Where are you going?" is functionally used as a verbal salute. An expected answer is "chotto soko made"--"just over there." Condon construes this verbal salute to be an example of Japanese small talk. ${ }^{61}$ Another verbal feature of American communication style is use of extreme or dichotomous expressions. Stewart remarks that thịs is tied to the American tendency to see the world in terms of black and white. 62 In this connection, Melvin Zax and Shigeo Takahashi studied Japanese and 
American response styles using the Rorschach inkblots. 63 Using a semantic differential scale, they found that the Japanese made significantly fewer extreme responses than did the Americans. The two speculate that the differences in response styles were caused by differences in childrearing practices between the two countries. In the case of the United States, Zax and Takahashi theorized that:

- . with the traditional American emphasis on personal initiative and resourcefulness, it is inevitable that the culture will be less inhibiting and less insistent on conformity than still that of Japan. 64

\section{Nonverbal Characteristics of} American Communication Style

It is widely believed that the characteristic of selfexpressiveness in American communication style appears not only in verbal behavior but also in nonverbal behavior. Americans use hands, body movements, and facial expressions (so-called kinesic behavior) more freely than do the Japanese. These movements in communication style are usually accompanied by verbal expressions, which are usually consistent in meaning with the nonverbal expressions. In other words, nonverbal behavior is used to reinforce verbal behavior in American communication style.

Contradicting the accepted view is Paul Ekman's study of universal facial expressions of basic emotions. 65 Ekman found that the same facial appearance expresses the same emotions regardless of culture. This he attributes to 
Charles Darwin's theory that the facial expressions of human beings and other primates have a common biological basis. However, Ekman also points out that there are some cultural differences in human expression. For example, although Japanese and Americans reacted to a stress film with strikingly similar facial expressions, the Americans were more apt during an interview to express negative feelings regarding their reactions. Ekman's study was not done in the context of social situations.

Contrary to a degree of similarity of facial expression (muscular reaction) between Japanese and Americans, the roles assigned to silence in each country are strikingly different. By and large, Americans hesitate to keep a moment of silence in their conversations. Johannesen notes that silence in Western culture is often viewed negatively. 66 In commenting on the study by Williams and Shamo, he remarks that:

- . the frequency of silent pauses used by a child was one criterion employed by American teachers to judge whether a child was culturally disadvantaged. The fewer times a child hesitated the less he was rated as culturally disadvantaged. 67

Johannesen also mentions Carpenter's comment that silence in Western culture is often regarded as an act of unfriendliness or disinterest. ${ }^{68}$ An exception, according to Bruneau, seems to relate to conceptions of man-made authority and conceptions of highest authority or God. 69 
Thought Pattern in American

Communication Style

The last element of American communication style is thought patterns, which can be described as the deep structure of communication style. Among the few published, studies on thought patterns, the interweaving of fact and logic and use of inductive and analytical thinking are identified as major characteristics of thought patterns in American communication style. 70 According to these studies a paragraph in American writing style is ordinarily constructed by the inductive method, defined as beginning with facts and then proceeding to a conclusion. 71 The initial facts are often supported by precisely footnoted quotations from scholarly writings. Stewart explores the relation between a concept and the inductive style in comparison to the European deductive style thus:

There is a teridency for the deductive individual to consider ideas as parts of the world of reality, to consider them as organic and alive. He may consider a new idea to be a "revelation" or a "discovery" while the more inductive American thinker will consider a concept more in the nature of a "construct" or an "invention."72

On this same topic Louis J. Moran studied the differences in cognitive dictionary structure through language development in children in Japan and the United States. 73 He established four different categories as follows: (1) iconic transformation yielded a word pair that ascribed a quality to the referent (e.g., apple-red); (2) enactive transformation 
yielded a word pair descriptive of an action upon the referent. (e.g., apple-eat); (3) functional transformation yielded a word pair naming two conjunctional physical referents (e.g., table-chair); (4) logical transformation yielded word pairs linked in what linguists term a "sense" relationship such as synonym and superordinates (e.g., blossom-flower-cabbage-vegetable). Results showed that Japanese and American children were similar in that the predominant transformations of both were enactive, i.e., concerned with "action upon referent." However, the shift from enactive to logical transformations was evidenced by American children and from enactive to iconic transformation by Japanese children by age ten.

Moran also tested the word associations of Japanese college women compared with American college women. 74 The results indicated that the American women scored highest on the dimension referent, defined as logical coordinate association and contrast association, while the Japanese women scored highest on the perceptual referent, which associates the stimulus word and response word, such as red-apple, or house-big.

These studies of word association indicate that the use of logic rather than dependence upon one's perception or feeling is clearly culturally predetermined, and is a phenomenon of the direct communication style. 
Finally, Cohen has introduced the concept of "rational" or "analytic" style, meaning a conceptual style based on essentially integrated rule-sets for the selection and organization of data. More particularly:

The analytic cognitive style is characterized by a formal or analytic mode of abstracting salient information from a stimulus or situation and by a stimulus-centered orientation to reality, and it is parts-specific. 75

In this regard, Stewart explains the dilemma of many foreign students enrolled in American universities--that of not presenting their ideas and thoughts analytically. To recapitulate briefly, the analytic style of the United States exphasizes individuality in human interaction and, hence, a direct communication style.

All in all, American communication style is acknowledged to be more direct than Japanese communication style in the sense that inner thoughts are expressed explicitly in a precise and logically sequenced description. American expressions are more verbally oriented. Hands, body movements, and facial expressions are used freely and generally in a manner consistent with the meaning of verbal expressions. 
Chapter 2--Notes

${ }^{I}$ Philip D. Stanhope, Speech, ed. Robert C. Jeffrey and Owen Peterson (New York: Harper and Row, Inc., 1975), p. 454.

${ }^{2}$ Donald C. Bryant and Karl R. Wallace, Fundamentals of Public Speaking, 4th ed. (New York: Meredith Corp., 1969), p. 192.

${ }^{3}$ Alma Johnson Sarett, Lew Sarett, and William Trufant Foster, Basic Principles of Speech (Boston: Houghton Mifflin Co., 1966), p. 43.

${ }^{4}$ Robert W. Norton, Lloyd S. Pettegrew, and Sherry Land, "Communication Style Correlates of Attraction," report to the International Speech Association Convention, Chicago, April 1974 (University of Michigan, 1974), p. 1.

${ }^{5}$ Larry D. Miller, "Dyadic Perception of Communication Style: Replication, Confirmation, and Theory," report to the Interpersonal Communication Division of the International Communication Association, Portland, Oregon, April 14-17, 1976 (Bloomington: Department of Speech Communication, Indiana University, 1976), p. 1.

6tanhope, p. 426.

7 Frederick C. Dyer, Executive's Guide to Effective Speaking and Writing (Englewood Cliffs: Prentice-Hall, Inc., 1962), p. 215 .

8 Norton, et al., p. 1 .

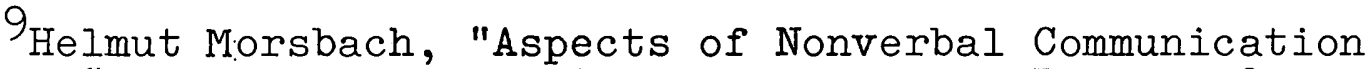
in Japan," in Intercultural Communication: A Reader, 2nd ed., edited by Larry A. Samovar and Richard E. Porter (Belmont, California: Wadsworth Publishing Co., Inc., 1976), p. 240 .

${ }^{10} \mathrm{John}$ I. Morrison, "The Absence of a Rhetorical Tradition in Japanese Culture," Western Speech (Spring 1972) p. 98 .

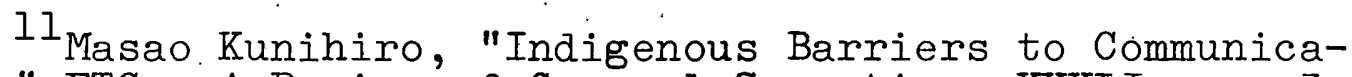
tion," ETC: A Review of General Semantics, XXXII, no. 3 (September 1975), p. 265.

12 Edwin 0. Reischauer, The United States and Japan, 3rd ed. (New York: The Viking Press, 1965), p. 163. 
${ }^{13}$ Chie Nakane, Kinship and Economic Organization in Rural Japan (London: The Athlone Press, University of London, 1967), p. 9.

${ }^{14}$ Idem, Tekio no Joken [Conditions for adaptation] (Tokyo: Kodan Publishers, 1972), p. 137.

${ }^{15}$ Takeo Doi, The Anatomy of Dependence (Tokyo: Kodansha Ltd., 1973).

16 Nakane, Tekio no Joken, p. 120.

17Dean C. Barnlund, Public and Private Self in Japan and the United States (Tokyo: The Simul Press, 1975), p. 32, 33.
18 Ibid., p. 33.
${ }^{19}$ Nakane, Kinship.., p. 9

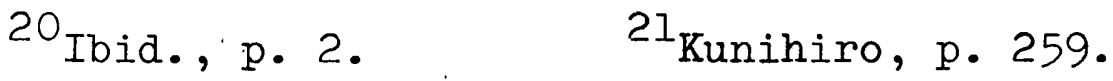
22 Morrison, p. 89. 23 Barnlund, p. 62.
${ }^{24}$ Winston I. Brembeck and William S. Howell,

Persuasion: A Means of Social Influence (Englewood Cliffs: Prentice-Hall, Inc., 1976), p. 27, 28.

${ }^{25} \mathrm{John}$ C. Condon and Fathis. Yousef, An Introduction to Intercultural Communication (Indianapolis: The BobbsMerrill Co., Inc., 1975), p. 237.

$26_{\text {Kunihiro, p. } 260 .}$

27 Reischauer, p. $123 . \quad 28$ Ibid., p. 122.

${ }^{29}$ Akira Tsujimura, Japanese Culture and Communication (Tokyo: Nihon.Hoso Shuppan Kyokai, 1973), p. 49.

$$
\text { 30 Ibid., p. 51. } \quad 31 \text { Kunihiro, p. } 260 .
$$

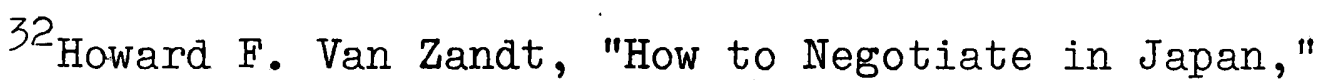
in Intercultural Communication: A Reader, 2nd ed., edited by Larry A. Samovar and Richard E. Porter (Belmont, California: Wadsworth Publishing Co., Inc., 1976), p. 308.

$$
33 \text { Reischauer, p. 116-117. } \quad 34 \text { Ibid. }
$$

- 35 Mark L. Knapp, Nonverbal Communication in Human Interaction (New York: Holt, Rinehart and Winston, Inc., 1972), p. 149. 
$\begin{array}{lr}37 \text { Ibid. } & 38 \text { Ibid., p. } 240 . \\ 39_{\text {Kunihiro, p. 267. }} & 40 \text { Ibid. }\end{array}$

${ }^{41}$ Earle Ernst, The Kabuki Theater (New York: Oxford University Press, 1956), p. 195-196.

42 Faubion Bowers, Japanese Theater (Rutland, Vermont: Continental Europe Boxerbooks, Inc., 1974), p. 240.

${ }^{43}$ A. C. Scott, The Puppet Theater of Japan (Rutland, Vermont: Charles E. Tuttle Company, 1963), p: 54 .

${ }^{44}$ Kunihiro, p. 264.

45 Personal visit to the annual flower arrangement exhibit of Sofu Teshigawara, Head of Sogetsu School, Fall 1970, Tokyo.

46 Kunihiro, p. 265.

47 Masao Kunihiro, "The Japanese Language and Intercultural Communication," The Japan Interpreter, X, no. 3-4 (Winter 1976), p. 267-283.

48 Ibid.

${ }^{49}$ Yoshihiko Kobayashi, "Toward True International Exchange," Japan Echo, III, no: 4 (1976), p. 142.

50 Ibid. $\quad{ }^{51}$ Ibid., p. 143. 52 Barnlund, p. 54.

53 Ibid., p. 19. · 54 Ibid., p. 62.

55 Andrew M. Greeley, Why Can't They Be Like Us?

(New York: E. P. Dutton and Co., Inc., 1971), p. 19.

$56_{\text {Mulford }} 0$. Sibley, "The Traditional American Doctrine of Freedom of Thought and Speech," The American Culture, ed. Henning Cohen (Boston: Houghton Mifflin Company, 1968), p. 169.

57 Ibid., p. 169.

${ }^{58}$ Edward C. Stewart, American Cultural Patterns: A Cross-Cultural Perspective (Regional Council for International Education: Dimensions of International Education, no.. 3, University of Pittsburgh, 1972), p. 21.

59 Eric Partridge, A Dictionary of Slang and Unconventional English (New York: Macmillan Co.), p. 514. 
${ }^{60}$ Paul D. Krivonos and Mark I. Knapp, "Initiating Communication: What D.o You Say When You Say Hello?" Central States Speech Journal, 26, no.2 (Summer 1975), p. 115-125.

$$
\text { 61 Condon, p. 22. } \quad 62 \text { Stewart, p. } 23 .
$$

63 Melvin Zax and Shigeo Takahashi, "Cultural Influence on Response Style: Comparisons of Japanese and American College Students," The Journal of Social Psychology, 71 $(1967), \mathrm{p} .4$.

64 Ibid.

65 Paul Ekman, "Face Muscles Talk Every Language," Psychology Today, 9, no. 4 (September 1975), p. 35, 36.

${ }^{66}$ Richard I. Johannesen, "The Functions of Silence: A Plea for Communication Research," Western Speech, 38, no. 1 (Winter 1974), p. 27.

$$
67 \text { Ibid. . } \quad 68 \text { Ibid. }
$$

${ }^{69}$ Thomas J. Bruneau, "Communicative Silences: Forms and Functions," The Journal of Communication, 23 (March 1973), p. 37 .

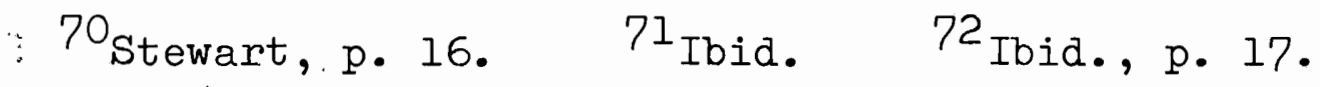

73 Louis J. Moran, "Comparative Growth of Japanese and North American Cognitive Dictionaries," Child Development, 44, no. 4 (1973), p. 863.

74 Idem, "Japanese and American Association Structures," Journal of Verbal Learning and Verbal Behavior; 7, no. 1 (February 1968), p. 177.

75 Rosalie A. Cohen, "Conceptual Styles, Culture Conflict, and Nonverbal Tests of Intelligence," American Anthropologist, 71 , no. 5 (October 1969), p. 829, 830. 


\section{CHAPTER III}

\section{BASIS FOR THE STUDY}

\section{BASIC ASSUMPTIONS}

A major basic assumption of this study is that human communication styles can be empirically studied through the observation and analysis of various mass-mediated cultures, particularly television advertising. This assumption is derived from the body of research showing that the genus culture reflects mass media and at the same time influences mass media. As expresised by Smythe:

The words, images, conventions of expression, and themes which make up TV content embody in various ways reference to "real" groups of people and individuals. The relation of TV content to the "real" world is a dialectical one: the TV "world" reflects the. "real" world on the one hand, and in turn changes the "real" world."

The statement is that cultural myths or leitmotives that are found in cultural symbols, beliefs, practices, and rhythms are reflected not only in art and dance, but also in mass media. The corollary is that the mass media reflects and influences the communication style of the genus culture. In this way the genus culture and mass media are : complementarily interactive. This characteristic is the reason interpersonal communication can be effectively studied through use of mass media. 
Moreover, it is important to point out that some form of mass media is more appropriate in the study of intercultural communication than actual communication samples, either "natural" (as occurring in society), or contrived in a laboratory setting. Natural samples contain numerous variables all of which would have to be accounted for in a controlled experiment. Comparative studies in intercultural communication must deal ith diverse cultural differences which make controls particularly important. All this makes it difficult to obtain appropriate samples by monitoring real-life situations. The artificial nature of laboratory samples also present many problems. Control is less difficult, but the appropriateness of applying finding to natural social settings is often questionable.

Of all forms of mass media, television commercials seem the most suitable for the study of cultural contrasts in communication style. One reason is that, unlike films and television dramas, television commercials are convenient for methodological purposes, i.e., they are short (15, 30, and 60 seconds), yet each contains a complete document. This makes it relatively easy to analyze the characteristics of a document and to determine the similarities and differences between documents.

Another major basic assumption used in this thesis is that television commercials simulate human communication styles. This assumption derives from the fact that the 
process of creating television commercials is done by members of the culture, and involves the marketing system and decision making process within the culture. Additionally, the cognitive system of consumers must be considered, otherwise they would not be persuaded by the commercials. Communication style in television commercials must be felt to be appropriate by the consumer if it is to be effective. It follows that the communication style of a television. commercial has a direct relationship to the communication style of the people of a culture.

It is interesting to compare what many advertising professionals say about communication style with what was noted in the general review of the literature. According to Mr. Gamo, ${ }^{2}$ vice president and General Manager of Dentsu Corporation of America (a branch of one of the world's largest advertising agencies), Japanese communication style emphasizes subtlety and sensitivity, while on the other hand American communication style is based upon the substantiation and embodiment of ideas and feelings. Regarding television commercials, it is his view that Japanese commercials more fully reflect Japanese cultural style than American commercials reflect American cultural style.

In commenting on Japanese communication style, Mr. John R. Thomson, an international marketing and communications consultant, adds that:

Japanese advertising does not generally stress product-oriented copy points. It goes more for 
moods, nuances and blue skies', based on belief and research which indicate that the Japanese consumer doesn't seem to recall product-oriented copy points very much. 3

He believes that this characteristic is the consequence of differences between the people who create advertising in Japan and the United States, rather than any differences in consumer behavior between the two countries. Television commercials are designed by representatives of the cultures who would, as a matter of course, use the style to which they have been acculturated. The main difference Thomson refers to is an emphasis on harmony in Japan, which he believes is fostered by the pattern of decision making common to Japanese business and an emphasis on close personal relationships between clients and professional advertising and marketing men. 4

In the same vein, Mukai, a researcher for Dentsu Advertising Itd. of Tokyo, points out that simplicity and logic are stressed in American commercials, while features totally unrelated to the product are emphasized in Japanese commercials. 5 He believes that this difference is due not only to cultural influences, such as the "haiku-like" sensitivity of the Japanese, but also to the effect of the Japanese marketing structure and industrial set-up of recent years. 6

However insightful, Thomson's and Mukai's attempts to explain advertising styles in terms of marketing techniques 
neglect the influence of cultural styles on television commercials. They are not fully aware that their observations regarding differences in the styles of Japanese and American commercials coincide with the differences in overall communication styles of the two countries as reported by numerous authorities.

\section{COMPONENTS OF COMIUUNICATION STYLE}

For the purpose of this study, five components of communication style were selected for analysis. These are: (1) character (who is communicating to whom), (2) content (choice of symbolic behavior to convey the meaning), (3) ratio of verbal to nonverbal behavior, (4) time span between verbal and nonverbal behavior, and (5) tone of voice.

\section{Character: Who is Communicating} to Whom

The first component of communication style, character of actor or presenter, is the role that is played. Goffman explains this first component by comparing the concept of an actor on the stage to the presentation of self in everyday life. More particularly, he defines the concept of a character as follows:

In our society the character one performs and one's self are somewhat equated, and this self-ascharacter is usually seen as something housed within the body of its possessor, especially the upper parts thereof, being a nodule, somehow, in the psychobiology of personality.? 
Goffman divides "self" into two basic parts--performer and character. A performer is always himself; a character is constantly shifted one to another by an individual. He also notes that character is often influenced by one's social and cultural role. As an example, if a student is talking to a professor or administrator, he speaks more formally than when he talks with his friends. In other words, he plays a role as a student in front of an authority figure, and plays the role of a friend among his friends.

In a traditional culture, the social and cultural role is much more precise than in a nontraditional culture. This makes character an indispensable determinant of communication style in a traditional culture. To illustrate: it is said that thirteen different linguistic levels are employed in the Japanese language. These levels are determined by the communicator's status, age, sex, and the like.

In the analysis of television commercials, the differences in the use of the character of actor or presenter between Japan and the United States are studied regarding this component.

Content: Choice of Symbolic

Behavior to Convey the Meaning

The second chosen factor of communication style is content, defined as the choice of verbal and/or nonverbal symbols to express thought. For example, when "love" is the goal of the message, there are several ways of conveying 
it, such as through gazing, kissing, or simply saying "I love you." Each of these expressions conveys the same meaning.

Content is often not considered an important element of communication style. In the United States it is usually the "way" something is said rather than "what" is said that is defined as style. This concept must be modified to take a homogeneous culture, such as Japanese, into account. Here a particular message is always presented by a prescribed pattern of behavior, verbal, nonverbal, or a combination of both. The content of a message is revealed by the pattern itself, not an individual analysis of language and behavior. As McLuhan would say, "The medium is the message, "8 within the homogeneous culture, the "what" that is chosen to express or subdue is part of communication style and conveys meaning as well as flavor.

It is easy to determine the content of messages transmitted in stylized form by persons within a homogeneous culture, except in cases pertaining to a special or unusual incident or occasion. The opposite is true when intercultural communication occurs. Values, beliefs, and social roles are very different between cultures, as are the patterns of behavior and choice of verbal and nonverbal expressions. For example, if a husband wants to show his love to his wife in American culture, he may simply say that he loves her, or may gaze at her and kiss her. 
But in Japan a husband does not ordinarily express his feeling toward his wife either verbally or nonverbally no matter how deeply he loves her. If it is possible to define the American expression of love as dynamic, the Japanese expression could be labeled as static.

The effective expression of "love" is almost opposite when the United States is compared to Japan. American message content to express the feeling of "love," is often the verbal expression "I love you," accompanied by the nonverbal expressions of gazing and kissing, while the Japanese content of the same message is expressed by silence. As this example shows, the content of a message can be very different in different cultures. This makes the choice of content an indispensable element in the study of communication style in intercultural communication between Japan and the United States.

Ratio of the Length of Verbal Expression to Nonverbal Expression

The ratio refers to the comparison and contrast of the length or duration of each of the verbal and nonverbal elements of an expression to the total length of the expression. The length of a verbal expression means the duration of oral presentation. The length of nonverbal expression is defined as the interval between presentations or during which silence is maintained. This ratio component refers to the contrast of the two lengths. 
As stated earlier, Japanese often hesitate to verbalize their thoughts, preferring to imply and hint. Accordingly, the Japanese tend to express their thoughts less verbally, and the length of their verbal expression is comparatively short. The opposite characteristic has been observed in the United States.

If these observations prove to be true empirically, the ratio of the length of verbal expression to nonverbal expression should differ between cultures.

\section{Time Span Between Verbal and}

Nonverbal Behavior

This specific concept of time span is derived from the theory of synchronization of speech and gesticulation originated by Condon and Ogston. They believe that "speech and gesticulation are totally synchronized, with speech calling the tune, and movement dancing to it."9 Within a culture a pattern of synchronization of the two behaviors is predetermined and is probably learned through language. acquisition. If Condon and Ogston's hypothesis that no gesture, not even an eye blink, is random is true, the time span between verbal and nonverbal behaviors indicates the rhythm of the two behaviors in a language and culture. However, the two behaviors are differently synchronized; whether verbal or nonverbal behavior occurs first in an expression, and the time span between the onset of when one follows the other, depend upon language and culture. 
In the analysis of Japanese and American television commercials, the differences in time span between initial visual display of the product and the announcement of the product is involved regarding this component.

\section{Tone of Voice}

Tone of voice is an aspect of paralanguage defined as the range of nonverbal vocal cues found in common speech behavior. ${ }^{10}$ According to Gibson, tone is a concomitant of style that is not meaningful by itself. 11 Tone seems to be associated with the intuitive feeling behind vocalization, which reflects the attitude of a communicator toward the topic of the conversation and toward other communicators.

In this study three different kinds of tone of voice, namely humorous, serious, and mixture, are used. These can be easily identified within one's own culture; it is rather difficult to recognize them in other cultures. This is because styles of mood expression differ between cultures. 
${ }^{I}$ Dallas W. Smythe, UNESCO, Reports and Papers on Mass Communication No. 70, Television Traffic--A One-Way Street? A Survey and Analysis of the International Flow of Television Programme Material (Kaarle Nordenstreng and Tapio Varis, 1974), p. 50 .

2 Interview with Toyosuke Gamo, Vice President and General Manager, Dentsu Corporation of America, August 9, 1977.

3 John R. Thomson, "How Coca-Cola's Hi-C Scored Success in Japan," Advertising Age (November 29, 1976), p. 33 .

${ }^{4}$ Ibid.

${ }^{5}$ Satoshi Mukai, "How Film Commercials Differ in Japan, U.S.," Dentsu's Japan Marketing Advertising (197576), p. 33 .

6 Ibid.

7 Erving Goffman, The Presentation of Self in Everyday Life (New York: Anchor Books, 1975), p. 128.

8Marshall McLuhan, Understanding Media: The Extensions of Man (New York: McGraw-Hill Book Company, 1964), p. 7 .

9 John C. Condon and Fathi Yousef, An Introduction to Intercultural Communication (Indianapolis: The BobbsMerrill Co., Inc., 1975), p. 128.

$1 \mathrm{O}_{\text {Mark I. Knapp, Nonverbal Communication in Human }}$ Interaction (New York: Holt, Rinehart and Winston, Inc., 1972), p. 7 .

ll Walker Gibson, "Hearing Voices: Tough Talk, Sweet Talk, Stuffy Talk, " in The Speaker's Reader: Concepts in Communication, ed. Robert I. Scott (California: Scott, Foresman and Company, 1969), p. 190. 


\section{CHAPTER IV}

\section{HYPOTHESES AND RATIONALES}

\section{THEORETICAL HYPOTHESIS}

The communication style of American television commercials is more direct than the communication style of Japanese television commercials.

\section{RESEARCH HYPOTHESES AND RATIONALES}

The basic theoretical hypothesis can be restated in six research hypotheses. The six are stated below followed by the rationale for each.

Hypothesis I: There will be a higher ratio of commercials using the character of a straight presenter (direct) as opposed to the character of an entertainer (indirect) in the United States than in Japan'.

Rationale. If someone takes the character of a presenter who persuades by providing information regarding a product in a straight fashion, he is defined as being more direct than someone who does not. Television commercials utilizing this character therefore stress product-oriented copy points. On the other hand, presenters who take the character of entertainers (such as cartoon characters, 
musical dancers, etc.) or roles (such as an understanding mother-in-law in dramatized television commercials), they may or may not introduce product information. In the latter case, the advertised products are presented as part of the entertainment in commercials utilizing performers. If performers are charged with the task of persuading and introducing product information, they do so in a much more indirect manner than a presenter.

Hypothesis II: There will be a higher ratio of commercials which present product information explicitly (direct) as opposed to it only being implied through verbal or nonverbal means (indirect) in the United States than in Japan.

Rationale. Explicitly stating and/or showing product information is more direct than implying such information. This is because "explicitness" in television commercials is characterized by the full and clear expression of product information through aural and visual stimuli. In contrast, advertisements that only imply product information typically focus on factors other than product-oriented copy points, such as the emotions of people, the latest fashions, or the current fad.

Hypothesis III: There will be a greater proportion of verbal (direct) to nonverbal (indirect) presentation in the United States than in Japan. 
Rationale. A higher proportion of verbal to nonverbal presentation is more direct than a lower proportion of verbal to nonverbal presentation. This is because a higher proportion of verbal presentation delivers more precise product information. On the other hand, with a lower proportion of verbal presentation, product information is indicated by inference and association rather than by direct statement. This makes it possible to interpret messages differently.

Hypothesis IV: The time span between initial visual display of the product and the verbal announcement of the product will be shorter (more direct) in the United States than in Japan.

Rationale. If the time span between the initial nonverbal display and the verbal announcement is short or none, the presentations are mutually supportive and the entire expression becomes explicit. On the other hand, when the two presentations occur at different times and the time span between the two is comparatively long, the presentations are less mutually supportive. The entire expression becomes less explicit and therefore less direct. Hypothesis V: There will be a higher ratio of commercials using a serious (direct) rather than a humorous (indirect) tone of voice in the United States than in Japan. 
Rationale. A serious tone is considered more direct than a humorous tone. A serious tone delivers only explicit product information. On the other hand, a humorous tone arouses the emotions of an audience by means of an emotive tone of voice, and in this way the attention of the audience tends to be diverted away from product information. Hypothesis VI: There will be fewer commercials that are accompanied with music (more direct) in the United States than in Japan.

Rationale. Television commercials with alower ratio of music are more direct than commercials with a higher ratio of music, because use of music stimulates the emotions and creates mood rather than a logical sense. 


\section{CHAPTER V. \\ METHODS AND PROCEDURES \\ POPULATION AND SAMPIING}

In the selection of the commercials to be studied, an effort was made to provide an adequate sample size and equal comparison of the time and day of the airing of the commercial. The time from 5:00 P.M. to 9:00 P.M. on Friday, May 13, 1977 was selected for three major reasons. One was to avoid any seasonal or special occasion influences, such as Christmas and New Year's Day in the winter season. Second, 5:00 P.M. to 9:00 P.M. presumably has a large viewing audience; therefore, there should be a wider variety of television commercials aimed at the total population, rather than just a selected group like housewives or children. Third, Friday was the only day of the week when it was possible to arrange for simultaneous videotaping during the prime viewing time in Japan and the United States. Third, the effect of Friday being the beginning to a weekend is offset by using a uniform sample from both cultures.

Fifty television commercials from each country were selected from the totals of 114 Japanese and 78 American television commercials that were broadcast during the time 
period. In order to select 50 television commercials in each country, they were classified into ten categories: liquor, soft drink, food, household product, toiletry, electric appliance, company and group, clothing, banking, and others. These categories were developed on the basis of my observations and by referring to categories used for the contest in the Annual of the All Japan Radio and Television Commercial Council. If a category was not advertised in one of the countries, the commercials of the category in the other country were eliminated. To illustrate: there were six American commercials that advertised services related to banking; these were eliminated from samples because no equivalent Japanese commercials appeared among the 115 television commercials.

Also, if a large number of television commercials were classified into a category in one of the countries, a subset of commercials were selected randomly from that category to reduce them to the same number of commercials that appeared in the same category in the other country. To illustrate: there were eight Japanese television commercials and six American commercials that advertised soft drinks. Six Japanese commercials were selected randomly from the original eight to make the number equal for both countries. 
Definition of Categories

\section{and Criteria}

Nonparametric tests, particuläly classificatory data analysis, are used for the analysis of hypotheses 1, 2, 5, and 6. Hypothesis 1 involves six discrete categories, hypotheses 2 and 6, two categories, and hypothesis 5, three ordered categories, that are not based upon their numerical values. Hypotheses 3 and 4 are focused on the differences between the means of two sets of scores. Tests of hypotheses 3 and 4 call for parametric tests. To provide data to test hypotheses 1, 2, and 5 three judges were employed to assign each commercial to a set of categories.

The definitions of categories for the nonparametric tests and the criteria for measurements of data in parametric tests were established by the experimenter as follows.

Hypothesis I

Two primary categories were considered in this analysis: (A) Straight Presenter, representing a direct communication style, and (B) Entertainer, representing an indirect communication style.

(A) Straight Presenter. In this category a straight presenter is someone who is not playing a role as an entertainer but is an informer-type person; that is, a celebrity or an authority, a consumer, an announcer or narrator, i.e., anyone who is speaking on behalf of the product 
or company. He or she often introduces a product outright to the audience, and often talks directly to the audience.

This primary category can be subdivided into three secondary categories.

Category 1: Celebrity, Authority

Primary method of presenting a product is that a celebrity or a professional gives information about a product as an authority in the field, or expresses his personal feelings about a product.

Category 2: Consumer Testimonial

Primary method of presenting a product is that a consumer interviewed by an announcer indicates the product's usefulness.

Category 3: Announcer, Narrator

Primary method of presenting a product is that a person or persons representing the company gives information about a product.

(B) Entertainer. In contrast with the straight presenter category, an entertainer usually plays a role as a performer such as a character in a cartoon, drama, or a dancer or singer in a musical production. The advertised product is often introduced as a part of the entertainment.

This primary category is also subdivided into three secondary categories. 
Category 4: Animation

Primary method of presenting a product is by a cartoon or animated form, such as an inorganic product presented as a living object which provides information about the product.

Category 5: Dramatization

Primary method of presenting a product is by an actor who is used to introduce a product in a fictitious story.

Category 6: Musical Production

Primary method of presenting a product is by singing and/or dancing which provides information about the product.

Hypothesis II

Two categories are considered in this analysis. Category 1: When there is description, function, value, and use of a product explicitly stated or shown visually. Therefore, the majority of content in this type of television commercial is product information.

Category 2: When product information is not explicitly stated; rather, the information is inferred and ambiguous, and the content of a television commercial is sometimes focused on more social and cultural aspects in everyday life. An 
advertised product is either implied or shown in context.

Hypothesis III

With respect to timing the length of a commercial, the following criteria were established:

Criterion 1: The total length of the verbal portion including the pauses between sentences is timed.

Criterion 2: Pauses between sentences longer than one second are not timed.

Criterion 3: Commercial songs or background music are not timed.

Hypothesis IV.

The following criteria were established to determine the time span between initial visual display of the product and the verbal announcement of the product.

\section{(A) Verbal Announcement.}

Criterion 1: The initial verbal announcement of a product is when the product's name is mentioned.

Criterion 2: A product initially introduced through the use of a commercial song is not included, nor is an informal product announcement by an actor as distinguished from the narrator.

\section{(B) Visual Display.}

Criterion 1: The initial visual display of a product includes a close-up of the product itself, 
as well as a close-up of an actor/actress with the product.

Criterion 2: An overview of the entire scene or a long shot is not included.

Hypothesis V

Three categories were used in testing this hypothesis. Category 1: Primary vocalized sound in the presentation of a product is humorous, comical, nonsensical, escapist, or dreamy.

Category 2: Primary vocalized sound in the presentation of a product is serious, realistic, or straightforward.

Category 3: Primary vocalized sound in the presentation of a product is the mixture of the two kinds of tone which are classified in the categories. 1 and 2.

Hypothesis VI

Two categories were used in testing this hypothesis. Category 1: Primary characteristic of the presentation of a product scored in this category is no music used throughout the whole commercial time.

Category 2: The primary characteristic of the presentation of a product scored in this category is the use of background music with or without lyrics, or the use of commercial songs. 


\section{DATA ANALYSIS}

\section{General Procedure}

Three judges were used to categorize the television commercials to provide data for testing hypotheses 1, 2, and 5. They were asked to assign each commercial to a set of categories. The data for testing the other hypotheses were obtained without the use of judges. In hypothesis 3, the length of the verbal to nonverbal presentation was measured three times by a stopwatch, and for hypothesis 4, the differences in time span between initial visual display of the product and the verbal announcement of the product were also timed three times by a stopwatch. The data for hypothesis 6 were processed by the experimenter without consulting other judges.

\section{Selection of the Judges}

In order to avoid a cultural bias, three judges were! chosen according to their cultural background and language abilities. An American, a Japanese-American, and a Japanese were selected. The American who had lived in Japan for three years understood Japanese fairly well. The JapaneseAmerican had visited Japan and understood Japanese very well. However, her first language was English. The Japanese judge had lived in the United States for three years and had the ability to communicate in English without any major problems. 
Training of the Judges

The three judges were instructed to assign each television commercial to a set of categories. They were given pretests before being given actual data. Each judge was given two sets of 50 scoring sheets, directions, and the list of 50 television commercials of each country. (See Appendix A and B.) The general purpose of the study was stated and the directions for coding were explained. However, the judges were not informed of the hypotheses during any point of the investigation.

\section{Inter-rater Reliability}

Various methods for assessing inter-rater reliability were considered for analyzing the extent of inter-rater agreement between judges in their categorizing data to be used to test hypotheses 1, 2, and 5. For hypothesis 1 that contains six discrete categories, a modification of Scott's $\pi$ was employed. ${ }^{1}$ scott developed an inter-rater reliability statistic, "pi."2 This statistic was specially designed to determine the agreement between two judges who had classified a large number of observer responses into nominal categories. Appendix C contains the formula for the modification of Scott's $\pi$ that is not calculated from percentile data but from raw data.

The Pearson product-moment correlation is used for analyzing the extent of inter-rater agreement between judges in their coding operation of data used to test hypotheses 2 
and 5. Since hypothesis 2 involves two categories and hypothesis 5 three sequential or ordered categories the Pearson product-moment correlation is adequate to analyze the inter-rater agreement between judges.

The actual work for analyzing inter-rater agreement between judges by the modification of Scott's $\pi$ and the Pearson product-moment correlation are cited in the chapter on results and discussion. 


$$
\text { Chapter 5--Notes }
$$

${ }^{I}$ Interview with Chadwick Karr and James A. Paulson, Department of Psychology, Portland State University, November 1977.

$$
{ }^{2} \text { William A. Scott, "Reliability of Content Analysis: }
$$
The Case of Nominal Scale Coding," Public Opinion Quarterly (Fall 1955), p. 321. 


\section{CHAPTER VI}

\section{RESUITS AND. DISCUSSION}

\section{RESUITS}

Hypothesis I: There will be a higher ratio of commercials using the character of a straight presenter (direct) as opposed to the character of an entertainer (indirect) in the United States than in Japan.

In this analysis, $x^{2}$ was employed to test differences between two independent groups of Japanese and American television commercials. With one degree of freedom at the .05 level the $\mathrm{X}^{2}$ value required for significance is 3.84 or greater. The resulting $x^{2}$ of .04 was not significant and the null hypothesis for differences in frequency for character of actor or presenter must be accepted. The results are summarized in Table $I$. 
TABLE I

OBSERVED FREQUENCY OF DIFFERENT

CHARACTER OF ACTORS

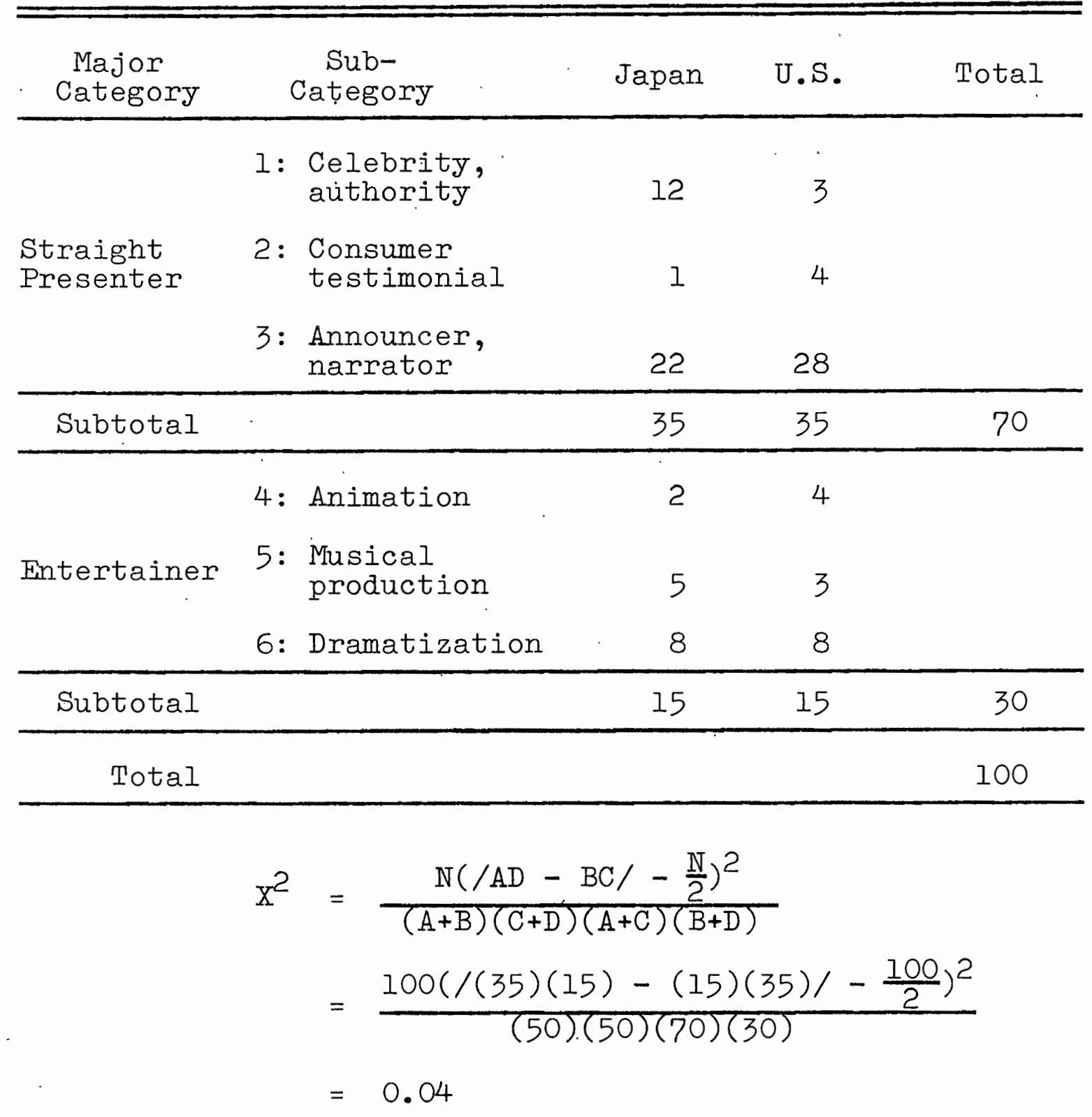

There was a significant difference between the two countries in the use of subcategories within a major category--Straight Presenter. Category I, Celebrity, Authority, was frequently used in Japanese television 
commercials; on the other hand, Category 3, Announcer, Narrator, frequently appeared in American commercials. $x^{2}$ was also employed for comparison of these two categories. The result of this test, as shown in Table II, was significant at the .0 .5 level.

TABLE II

OBSERVED FREQUENCY FOR CATEGORIES 1 AND 3

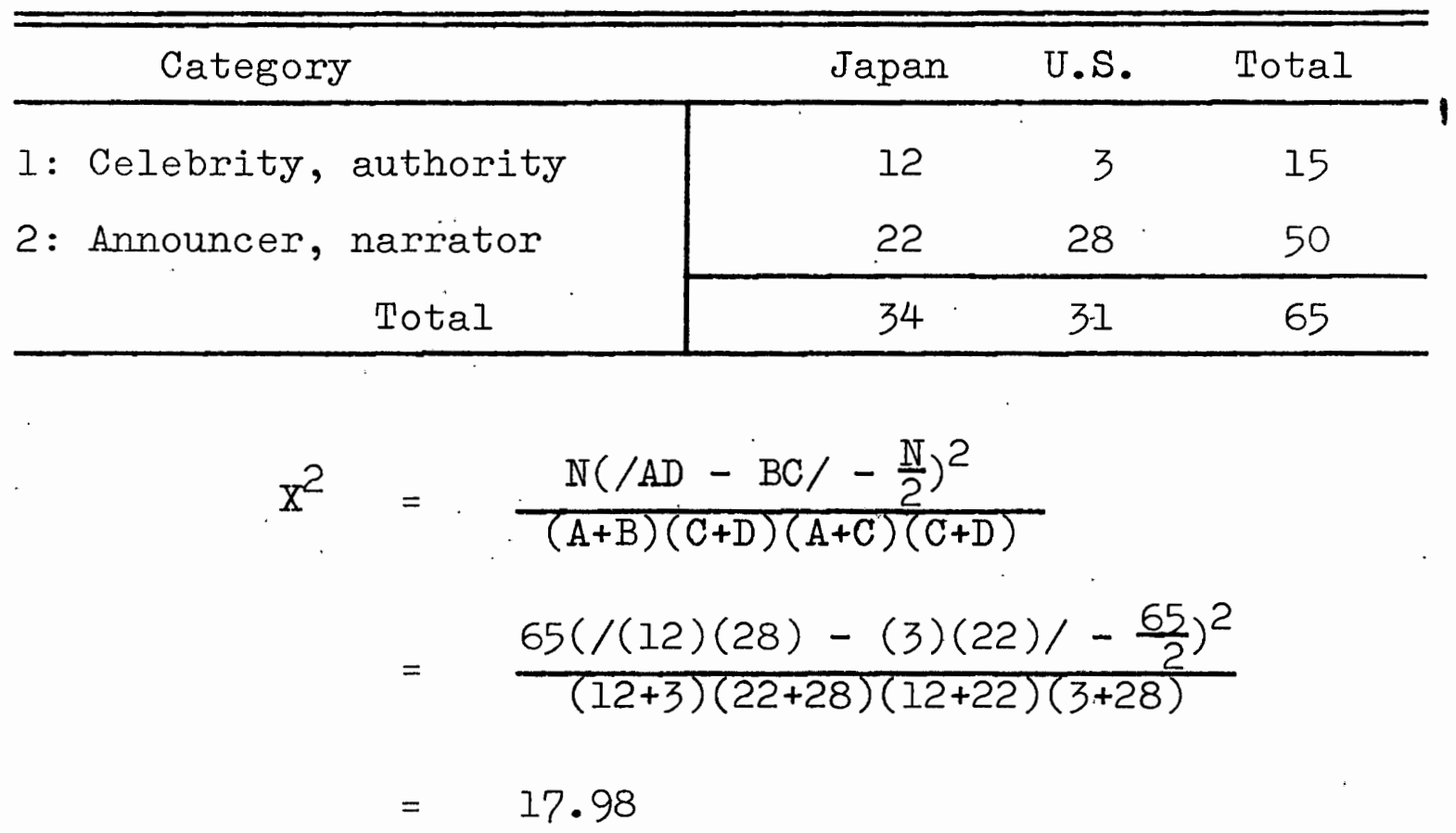

(To be statistically significant, a $x^{2}$ value of 3.84 or greater is required.)

Hypothesis II: There will be a higher ratio of commercials which present product information explicitly (direct) as opposed to it only being implied through verbal or nonverbal means (indirect) in the United States than in. Japan. 
The choice of explicitness in content was very highly significantly different between Japanese and American television commercials. The $x^{2}$ was also employed in this operation. The null hypothesis was rejected. The information leading to these results appears in Table III.

\section{TABIE III}

OBSERVED FREQUENCY FOR EXPIICITNESS OF CONTENT

\begin{tabular}{|c|c|c|c|}
\hline Category & Japan & U.S. & Total \\
\hline l: Explicit & 22 & 49 & 71 \\
\hline 2: Implicit & 28 & 1 & 29 \\
\hline Total & 50 & 50 & 100 \\
\hline
\end{tabular}

$$
\begin{aligned}
x^{2} & =\Sigma\left[\frac{(O-T)}{T}\right]^{2} \\
& =32.83
\end{aligned}
$$

(To be statistically significant, $x^{2}$ value of 3.84 or greater is required at the .05 level with one degree of freedom.)

Hypothesis III: There will be a greater proportion of verbal (direct) to nonverbal (indirect) presentation in the United States than in Japan.

In order to investigate the effect of differences in the total length of differences in the length of television commercials (15, 30, and 60 seconds), two separate tests were performed in this study. 
(1) 30-second length television commercials. Fortynine 30-second American commercials and fifteen 30-second Japanese commercials were involved in this analysis. Student's $\underline{t}$ for two independent samples was used to determine whether the difference in the means was statistically significant. The resulting student's t value, as shown in Table IV, was significant at the .05 level.

(2) 15-, 30-, and 60-second length television commercials. In this analysis, all commercials were involved. In order to obtain equivalent comparisons, the length of verbal presentation for each observation was divided by the total time of the observation. Student's $t$ was employed. The resulting was highly significant, as shown in Table IV.

\section{TABLE IV}

SUMMARY OF STUDENT'S t RESULTS FOR THE PROPORTION OF VERBAI PRESENTATION TO NONVERBAL PRESENTATION

\begin{tabular}{|c|c|c|c|c|c|c|c|}
\hline Comparison & $\mathrm{N}$ & d.f. & $\mathrm{M}_{\mathrm{X}}$ & $\mathrm{M}_{\mathrm{y}}$ & $S D_{x}$ & $S D_{y}$ & $t$ \\
\hline $\begin{array}{l}\text { 30-second TV } \\
\text { commercials } \\
\text { in Japan and } \\
\text { the U.S. }\end{array}$ & $\begin{aligned} J & =15 \\
U . S . & =49\end{aligned}$ & 62 & 23.42 & 15.66 & 8.28 & 8.69 & 3.13 \\
\hline $\begin{array}{l}\text { 15-, 30-, 60- } \\
\text { second TV } \\
\text { commercials } \\
\text { in Japan and } \\
\text { the U.S. }\end{array}$ & $\begin{array}{r}J=49 \\
\text { U.S. }=49\end{array}$ & 96 & .78 & .52 & .27 & .25 & 4.87 \\
\hline
\end{tabular}

(To be statistically significant, the student's $t$ value of 1.96 or greater is required at the .05 level for a two-tailed 
test. Both sets of results were significant; therefore, the null hypotheses were rejected.)

In summary, these two results make clear that differences in the total length of television commercials did not have a significant effect on the ratio of verbal presentation to nonverbal presentation.

Hypothesis IV: The time span between initial visual display of the product and the verbal announcement of the product will be shorter (more direct) in the United States than in Japan.

For both countries there were two television commercials in which the message was presented entirely in the form of commercial song.s. In order to avoid an effect on verbal presentation from the use of a commercial song as the main method of product information, those commercials were eliminated from this study. Therefore, the number of samples used were 48 for each country.

Both the Median Test and the Mann-Whitney U test were used to determine whether two independent groups have been drawn from the same population using ordinal measurement. As shown below, the results of the $X^{2}$ and the $U$ tests were both highly significant; therefore, the null hypothesis was rejected.

(1) The Median Test for Differences in Time Span Between Initial Visual Display of the Product and the Verbal Announcement of the Product 
TABLE, V

MED IAN. TEST: FORM FOR DIFFERENCES IN TIME SPAN

\begin{tabular}{l|ccc}
\hline & Japan & U.S. & Total \\
\hline $\begin{array}{l}\text { No. of TV commercials } \\
\text { above combined } \\
\text { median }\end{array}$ & 33 & 13 & 46 \\
\multirow{2}{*}{$\begin{array}{l}\text { No. of TV commercials } \\
\text { below combined } \\
\text { median }\end{array}$} & 15 & 55 & 50 \\
\cline { 2 - 4 } Total & 48 & 48 & 96 \\
\hline
\end{tabular}

$$
\begin{aligned}
X^{2} & =\frac{N\left(/ A D-B C /-\frac{N}{2}\right)^{2}}{(A+B)(C+D)(A+C)(B+D)} \\
& =\frac{96\left(/(33)(35)-(13)(15) /-\frac{96}{2}\right)^{2}}{(46)(50)(48)(48)} \\
& =15.06
\end{aligned}
$$

(To be statistically significant, an $x^{2}$ value of 3.84 or greater is required.) 
(2) The Mann-Whitney U-Test for Large Samples

$$
\begin{aligned}
U & =\left(N_{1}\right)\left(N_{2}\right)+\frac{N_{1}\left(N_{1}+1\right)}{2}-R_{1} \\
& =(48)(48)+\frac{48(48+1)}{2}-1721 \\
& =1759 \\
z & =\frac{U-\frac{\left(N_{1}\right)\left(N_{2}\right)}{2}}{\frac{\left(N_{1}\right)\left(N_{2}\right)\left(N_{1}+N_{2}+1\right)}{2}} \\
& =\frac{1759-\frac{(48)(48)}{2}}{\frac{(48)(48)(48+48+1)}{2}} \\
& =4.44
\end{aligned}
$$

(To be statistically significant, a $\mathrm{z}$ value of 1.96 or greater is required at the .05 level for a two-tailed test.)

Hypothesis V: There will be a higher ratio of commercials using a serious (direct) rather than a humorous (indirect) tone of voice in the United. States than in Japan. $\mathrm{x}^{2}$ was employed in this analysis to test differences in the use of vocalized sound between Japanese and American television commercials. The resulting $\mathrm{x}^{2}$ was not statistically significant. (See Table VI.) Therefore, the null hypothesis was accepted. 
TABLE VI

OBSERVED FREQUENCY OF D IFFERENCE

IN THE VOCALIZED SOUND

\begin{tabular}{l|rcc}
\hline \hline Category & Japan & U.S. & Total \\
\hline 2: Serious & 25 & 28 & 53 \\
3: Mixture & 9 & 12 & 21 \\
1: Humorous & 16 & 10 & 26 \\
\cline { 2 - 4 } & 50 & 50 & 100 \\
\hline
\end{tabular}

$$
\begin{aligned}
X^{2} & =\Sigma\left[\frac{(O-T)}{T}\right]^{2} \\
& =4.08
\end{aligned}
$$

(To be statistically significant, $x^{2}$ value of 5.99 or greater is required at the .05 level with two degrees of freedom.)

Hypothesis VI: There will be fewer commercials that are accompanied with music (more direct) in the United States than in Japan.

A $\mathrm{X}^{2}$ test was also applied in this analysis to test differences in the extent of music used between Japanese and American television commercials. The resulting $x^{2}$, as shown in Table VII, was significant. Therefore, the null hypothesis was rejected. 
TABLE VII

OBSERVED FREQUENCY OF DIFFERENCE

IN THE EXTENT OF MUSIC USED

\begin{tabular}{|c|c|c|c|}
\hline Category & Japan & U.S. & Total \\
\hline $\begin{array}{l}\text { 1: Commercials with } \\
\text { music }\end{array}$ & 41 & 23 & 68 \\
\hline $\begin{array}{l}\text { 2: Commercials without } \\
\text { music }\end{array}$ & 9 & 27 & 32 \\
\hline Total & 50 & 50 & 100 \\
\hline
\end{tabular}

$$
\begin{aligned}
x^{2} & =\quad \sum\left[\frac{(O-T)}{T}\right]^{2} \\
& =7.76
\end{aligned}
$$

(To be statistically significant, a $x^{2}$ value of 3.84 or greater is required.)

Inter-rater Reliability of Judges

The modification of Scott's $\pi$, which was mentioned in the previous chapter, was. employed to analyze the extent of inter-rater agreement among three judges in their assigning of each commercial to one of a set of six categories to provide data to test hypothesis 1. The interrater agreement between judge II and III for Japanese commercials by the modification of Scott's $\pi$ is illustrated by the analysis of the data presented in Table VIII. The summary of inter-rater reliability results is reported in Table IX. 


\section{TABIE VIII}

\section{OBSERVED FREQUENCY OF ASSIGNMENTS BY JUDGES II AND III OF JAPANESE TELEVISION COMMERC IALS}

\begin{tabular}{|c|c|c|c|c|c|c|c|c|}
\hline & \multirow[b]{2}{*}{ Category } & \multicolumn{6}{|c|}{ Judge II } & \multirow[b]{2}{*}{ Total } \\
\hline & & 1 & 2 & 3 & 4 & 5 & 6 & \\
\hline \multirow{7}{*}{$\begin{array}{l}H \\
H \\
H \\
0 \\
80 \\
0 \\
ٌ \\
5\end{array}$} & 1 & 3 & & & & & & $\left(\begin{array}{l}3 \\
06\end{array}\right)$ \\
\hline & 2 & & $(.08)$ & & & & & $\left(\begin{array}{l}4 \\
(.08)\end{array}\right.$ \\
\hline & 3 & & & $(.1 / 02)$ & $(. \stackrel{1}{.02})$ & & & $\begin{array}{l}2 \\
(.04)\end{array}$ \\
\hline & 4 & & & & $\begin{array}{c}5 \\
(.10)\end{array}$ & & & $\begin{array}{l}5 \\
(.10)\end{array}$ \\
\hline & 5. & & & & $(.02)$ & $\begin{array}{l}7 \\
.14)\end{array}$ & & $\begin{array}{l}8 \\
(.16)\end{array}$ \\
\hline & 6 & $(.04)$ & $(. .02)$ & & $\left(\begin{array}{l}2 \\
(.04)\end{array}\right.$ & & $\begin{array}{c}23 \\
(.46)\end{array}$ & $\begin{array}{l}28 \\
(.56)\end{array}$ \\
\hline & Total & $(.5)$ & $\begin{array}{l}5 \\
(.10)\end{array}$ & $(.02)$ & $\begin{array}{c}9 \\
(.18)\end{array}$ & .74 & $\begin{array}{c}23 \\
(.46)\end{array}$ & $\begin{array}{c}50 \\
(1.00)\end{array}$ \\
\hline
\end{tabular}

anmber in () is the proportion of the corresponding frequency to the total frequency which is 50 .

Expected Agreement $=$ Sum of Row Proportion $\mathrm{x}$ Column Proportion for Agreeing Cells

$$
\begin{aligned}
& =(.06)(.01)+(.08)(.10)+(.04)(.02)+ \\
& =(.10)(.18)+(.16)(.14)+(.56)(.46) \\
& =30
\end{aligned}
$$

Observed Agreement $=$ Sum of Proportions in Agreeing Cells

$=(.06)+(.08)+(.02)+(.10)+(.14)+(.46)$

$=.86$ 
Modification of Scott's $\pi$

$$
\begin{aligned}
& =\frac{\text { Observed Agreement }- \text { Expected Agreement }}{1}-\text { Expected Agreement } \\
& =\frac{(.86)-(.30)}{1-(.30)} \\
& =.80
\end{aligned}
$$

TABLE IX

INTER-RATER RELIABILITIES IN CATEGORIZING TELEVISION COMMERCIAIS

\begin{tabular}{l|cccc}
\hline \hline Country & Judges I, II & Judges & II, III & Judges I, III \\
\hline Japan & .63 & .80 & .51 \\
U.S. & .70 & .80 & .56 \\
\hline
\end{tabular}

Unlike the six discrete categories which are involved in the test of hypothesis 1, the test of hypothesis 2 involves two categories, and the test of hypothesis 5 involves three categories that are sequential. Therefore, the Pearson product-moment correlation was used to analyze the extent of inter-rater agreement among the three judges in their coding operation of the data used to test hypotheses 2 and 5. To illustrate, the computation of inter-rater agreement between judges II and III in their coding operation of data used to test hypothesis 2 for American television commercials is given below, and the summary of interrater reliability results is reported in Table $\mathrm{X}$. 
Calculation of Pearson product-moment correlation:

$$
r=\frac{\sum_{i=1}^{n} \sum_{i}\left(x_{i}\right)\left(y_{i}\right)-\left(\sum_{i=1}^{n} x_{i}\right)\left(\sum_{i=1}^{n}\right)}{\sqrt{n_{i=1}^{n} x_{i}^{2}-\left(\sum_{i=1}^{n} x_{i}\right)^{2}} \sum_{i=1}^{n} \sum_{i}^{2}-\left(\sum_{i=1}^{n} y_{i}\right)^{2}}
$$

$\mathrm{x}_{i}=\mathrm{a}$ value of $i$-th category observed by judge II

$y_{i}=$ a value of $i$-th category observed by judge III

when Category 1: Explicit Content is assumed as value one, and Category 2: Implicit Content is assumed as value two.

$$
\begin{aligned}
x_{i}=51 \quad y_{i} & =54 \quad\left(x_{i}\right)\left(y_{i}\right)=56 \quad x_{i}^{2}=53 \quad y_{i}^{2}=62 \\
r & =\frac{(50)(56)-(51)(54)}{\sqrt{(50)(53)-(51)^{2}(50)(62)-(54)^{2}}} \\
& =.48
\end{aligned}
$$

TABLE X

INTER-RATER RELIABILITIES IN CODING DATA

FOR TESTING HYPOTHESES 2 AND 5

\begin{tabular}{l|cccc}
\hline Hypothesis & Country & $\begin{array}{l}\text { Judges } \\
\text { I, II }\end{array}$ & $\begin{array}{l}\text { Judges } \\
\text { II, III }\end{array}$ & $\begin{array}{l}\text { Judges } \\
\text { I, III }\end{array}$ \\
\hline $\begin{array}{l}\text { 2. Explicit- } \\
\text { ness in } \\
\text { content }\end{array}$ & Japan & .25 & .87 & .25 \\
& U.S. & - & .48 & - \\
$\begin{array}{l}\text { 5: Vocalized } \\
\text { sound }\end{array}$ & Japan & .74 & .75 & .79 \\
\hline
\end{tabular}




\section{INTERPRETATION OF FINDINGS}

Hypothesis I

The findings indicate that there is no significant difference in the use of character of actors or presenter (straight presenters or entertainer) between Japanese and American television commercials. In each country the number of commercials involving a straight presenter using direct communication style amounted to 70 percent of the total number of television commercials presented. This finding is probably due to the fact that the purpose of television commercials in both Japan and the United States is to present product information, rather than due to any similarity in the cultural styles of the two countries. In other words, the finding may be due to the cross-cultural homogeneity in the style of advertisement.

A significant difference in the use of celebrityauthority vs. announcer-narrator between Japanese and American commercials was found within a major category, the straight presenter. In detail, commercials presented by the celebrity-authority accounted for 24 percent of the total number of Japanese commercials. This finding indicates that use of fame is an effective strategy in Japanese commercials, and is the embodiment of the good repute of a product. 
In marked contrast, 80 percent of American television commercials were presented by the use of announcer-narrator within the straight presenter category.

\section{Hypothesis II}

The analysis of the explicitness of content, defined as the choice of symbolic behavior to convey meaning, produced the assumed results. Japanese commercials employed indirect expressions in that the product slogans were often implied through abstract, sensual, and suggestive means. This phenomenon reflects a tendency to avoid use of explicit expressions, verbally or nonverbally, in Japanese human communication style. The reason is that explicitness is often interpreted as aggressiveness, and this is not considered a proper way of expressing oneself among the Japanese.

To the contrary, explicitness of content in American commercials was characterized by clear expression. The message in American commercials involved clear, factual, and logical presentation of product information. This presumably indicates the tendency in American human behavior to use direct communication style based upon facts and logic.

\section{Hypothesis III}

The analysis of ratio of length of time used for verbal presentation to nonverbal presentation revealed 
significant differences between Japanese and American television commercials. Verbal presentation accounted for only 25 percent of the total length of Japanese commercials, but for 84 percent of the total length of American commercials. The Japanese result supports Morrison's view regarding the absence of a rhetorical tradition in Japanese culture, and also Kunihiro's view regarding the high value placed by the Japanese of reticence and their disapproval of the verbalization or open expression of one's inner thoughts. The American result probably indicates that the verbalization of thoughts and feelings is the most common way of conveying a message in American communication style.

\section{Hypothesis IV}

Analysis of difference in time span between visual display of the product and the verbal announcement of the product between Japanese and American commercials produced the most significant findings of the study. The results indicated that the timing of verbal and nonverbal presentation in the American commercials tended to be concurrent, with the nonverbal presentation sometimes even occurring after the verbal presentation. This result corroborates Condon and Ogston's theory regarding the synchronization of speech and gesticulation in American communication style. In view of this fact, it is possible to interpret the nonverbal aspect of expression as reinforcing the verbal 
aspect in American communication style. This finding is strong evidence that American communication style is straightforward and direct.

In the case of Japanese television commercials the timing of the initial visual display of the product and verbal announcement of the product was inconsistent not only in the expression of meaning, but also in synchronization. To take a non-television example: in Japan it is common for a person's facial expression to remain impassive or even covered with a smile while he is relating a misfortune or sorrow. The symbolized meaning of the verbal and nonverbal expressions are of course inconsistent.

The consistency between verbal and nonverbal expressions in Japanese communication style also appears in the timing between the two behaviors. As the analysis of hypothesis 4 indicated, the time span between visual display of the product and the verbal announcement in Japanese commercials is longer than in American commercials, and visual display tends to precede verbal announcement. These findings also indicate, as mentioned under hypothesis 3 , that nonverbal behavior is more commonly used among the Japanese as a means of expressing one's feelings. In this connection, a significant point made by Condon is that "to learn a foreign language it is necessary to learn not only the sounds of the language, but also to learn to blink and twitch in a new rhythm." 1 
Hypothesis V

The assumed result regarding vocalized sound was not realized in the study. The proportions of use of serious tone, mixed tone, and humorous tone in both countries were similar; about 50 percent of television commercials were presented by serious tone in both countries. In common with the results for hypothesis 1 , this finding probably reflects the fact that the purpose of television commercials in both countries is to present product information, rather than due to any similarity in the cultural styles of the two countries.

\section{Hypothesis VI}

As indicated, about 80 percent of Japanese television commercials employed some form of music, whereas less than 50 percent of American commercials used music in their presentations. This reflects Mukai's report that Japanese commercials often attempt to create a sentimental or humorous atmosphere. ${ }^{2}$ For building this atmosphere music is indispensable. In contrast, use of music is not common in American commercials. This is probably because the American reasoning style is based on logic rather than emotion. These results indicate an emphasis on emotion in Japanese communication style, and an emphasis on logic in American communication style. 
Iimitations of the Study

There are two major difficulties involved in this study. One is the problem of sampling. On American television the kinds of products advertised are greatly influenced by the audience. To illustrate, there are many advertisements of women's personal products and home care products on daytime television. These are often presented by comparison with other products or by demonstration of how a product was improved, etc. Nighttime television commercials are also focused in terms of the kind of product and the method of presentation in some degree. ${ }^{3}$ This makes it difficult to collect different kinds of American commercials within a few consecutive hours. Theoretically, the analysis of all television commercials broadcast throughout a whole day would be more representative of American culture. In the case of Japan, according to Mr. Maeda, the Chief of International Relations at Mainichi Broadcasting System, time of day does not strongly influence the kinds of products advertised. ${ }^{4}$

Secondly, there are some difficulties in training of. judges. Since studies 1, 2, and 5 were nonparametric, it was necessary to examine inter-rater reliability. The differences in relative fluency of judges in Japanese and English and in their understanding of the two cultures made it difficult to achieve a high degree of agreement between 
judges. For example, with comprehending names and faces of celebrities in both cultures, it was impossible to achieve a significant degree of reliability between judges regarding the study of the role of character.

In this study, three judges were selected based upon their language abilities and cultural backgrounds. However, judge I had visited Japan only a few times, so that it was difficult for her to understand the implication of cultural context in Japanese commercials. Consequently, the level of inter-rater reliability between judges II and III were higher than the level between judge I and II and between judge I and III.

\section{SUGGESTIONS FOR FUTURE RESEARCH}

Rhetorical form, defined by Condon as the selection and manner of presentation of proofs in an appropriate form for a given audience to secure belief, ${ }^{5}$ might usefully be explored as a component of communication style in future research, particularly with regard to the reasoning style and the organization of presentations.

Relativity of rhetorical forms is a theory advocated by Condon based. upon his approach to value orientations. Perhaps, this can be used for analyzing communication styles among different cultures in everyday life. This is because people are constantly and unconciously persuading others or being persuaded by others. 
The differences in rhetorical form between Japanese and American communication styles can be studied not only from Condon's approach but also from the standpoint of cognition. In particular, the study of Moran's word association indicates that Japanese tend to use perceptual referents (e.g., red-apple), which are often a graphic description, as opposed to dimension referents of logical coordination (blue-yellow) or contrast association (darklight) by Americans. ${ }^{6}$ Also, rhetorical form can be studied from the use of relational and analytic cognitive style developed by Cohen. ${ }^{7}$ Cognitive differences would be reflected in the differences in rhetorical forms. To illustrate, in Japanese culture, the graphic description tends to be accepted as reasoning style whereas only logical proofs are accepted in American culture. These rhetorical aspects of communication style can be studied by analyzing such mass media as newspapers, radio, and television. Television commercials also may be useful in the $\mathcal{X}$ study of roles in a culture. For example, whether or not a male presenter of a product employs more verbalization than a female product presenter reveals an aspect of sexual roles. It would be especially interesting to compare differences in the way the same products (Toyota, Sony, Coca-Cola, etc.) are advertised in different countries. 
Chapter 6--Notes

${ }^{1}$ John C. Condon and Fathi Yousef, An Introduction to Intercultural Communication (Indianapolis: The BobbsMerrill Company, Inc., 1975), p. 128.

$2_{\text {Satoshi Mukai, "How Film Commercials Differ in }}$ Japan, U.S.," Dentsu's Japan Marketing Advertising (197576), p. 33.

3 Based on personal two week survey of television commercials.

${ }^{4}$ Letter from Jiro Maeda, International Relations, Mainichi Broadcasting System Inc., April 4, 1977.

${ }^{5}$ Condon, p. 189.

6Luis J. Moran and Noriko Murakawa, "Japanese and American Association Structures, "Journal of Verbal Learning and Verbal Behavior, no. 7 (1968), p. 176-181.

7 Rosalie A. Cohen, "Conceptual Styles, Culture Conflict, and Nonverbal Tests of Intelligence, " American Anthropologist, 71 (1969), p. 829-830. 


\section{CHAPTER VII}

\section{CONCLUSION}

This study has been an empirical analysis of communication styles in Japan and the United States. In particular the study dealt with communication styles in Japanese and American television commercials as a reflection of human communication styles in the two countries.

In a review of the literature, studies describing the characteristics of human communication styles in Japan and the United States were surveyed. Iack of verbalization, high value placed on silence, and importance of facial expression were identified as major characteristics of (indirect) communication style in Japan. An emphasis on verbalization, especially with regard to being specific, and use of dichotomous expressions were identified as major characteristics of (direct) communication style in the United States.

In order to determine whether or not these characteristics of communication styles are reflected in Japanese and American television commercials, five components of communication style were suggested. These are (I) character (who is communicating to whom), (2) content (choice of symbolic behavior to convey the meaning), (3) ratio of 
verbal to nonverbal behavior, (4) time span between verbal and nonverbal behavior, and (5) tone of voice.

Next, six research hypotheses were constructed based upon the following theoretical hypothesis: the communication style of American television commercials is more direct than the communication style of Japanese television commercials. The six research hypotheses were structured from the five components of communication style indicated above.

For testing the research hypothesis, 50 television. commercials were selected respectively from 114 Japanese television commercials and 78 American television commercials videotaped during the hours between 5:00 and 9:00 P.M. on Friday, May 13, 1977.

The results indicated no difference in the use of 7 character of actor or presenter between Japanese and American commercials. There was a difference between the use of narrator-announcer and use of celebrity-authority in a major category, that of straight presenter, however. Japanese commercials employed larger use of celebrityauthority than of announcer-narrator, whereas the opposite result was found for American commercials.

The result of testing research hypothesis 2, content (choice of symbolic behavior to convey meaning), was highly significant. Japanese commercials were found to employ more implicit than explicit content, whereas the 
opposite result was found for American television commercials.

Hypothesis 3 dealt with the study of difference in the ratio of the length of verbal to nonverbal presentations. The results were highly significant, with verbal presentation accounting for only 50 percent of the total length of Japanese commercials, whereas 80 percent of the total length of American television commercials consisted of verbal presentation.

Hypothesis 4 involved the difference in the time span between initial visual display of the product and the verbal announcement of the product in the commercials of the two countries. An important finding was that the time span between the two presentations in Japanese commercials was significantly longer than the time span in American commercials.

The results from testing hypothesis 5 were not statistically significant. More than 50 percent of both Japanese and American television commercials were found to employ serious tone rather than a mixture or humorous tone as had been predicted.

Finally, hypothesis 6 dealt with differences in the degree of the use of music. The result was statistically significant. More than 80 percent of Japanese commercials were accompanied by music, whereas less than 50 percent of American commercials were so accompanied. 
The major conclusion reached is that the communication styles revealed in their television commercials are generally indirect in Japan and generally direct in the United States. Typically, in a Japanese commercial an advertised product is presented less verbally than in an American commercial. Accompanied by music, the Japanese? advertisement will begin with a close-up of the product $y$ followed by an announcement of the product's name. The explicitness of the content is low; messages are usually; implied and hinted.

On the other hand, the typical product in an American television commercial is presented by explicit verbal description, simultaneous with a close-up of the product and the announcement of the product name, without the accompaniment of music.

The results of the study clearly reflect the elements of indirectness in Japanese human communication style. These include high value attached to silence, low verbalization, and implication rather than explicit expression of thoughts. As for the United States, the results reflected the elements of directness in human communication style. These elements include verbal orientation, explicitness in verbal description, and consistency between verbal and nonverbal behavior. 


\section{BIBLIOGRAPHY}

Barna, LaRay M. "Intercultural Communication Stumbling Blocks," in Intercultural Communication: A Reader. 2nd ed. Edited by Iarry A. Samovar and Richard E. Porter. Belmont, California: Wadsworth Publishing Company, Inc., 1976, 291-297.

Barnlund, Dean C. Public and Private Self in Japan and the United States. Tokyo: The Simul Press, 1975.

Beier, Ernst G. The Silent Language of Psychotherapy: Social Reinforcement of Unconscious Processes. Aldine Publishing Company, 1968.

and Alexander Zautra. "Identification of Vocal Communication of Emotions Across Cultures, "Journal of Consulting and Clinical Psychology, 39, No. 1 (1972), 166 .

Bowers, Faubion. Japanese Theatre. Rutland, Vermont: Continental Europe Boxerbooks, Inc., 1974.

Brembeck, Winston I. and William S. Howell. Persuasion: A Means of Social Influence. 2nd ed. Englewood Cliffs: Prentice-Hall, Inc., 1976.

Bruneau, Thomas J. "Communicative Silences: Forms and Functions," The Journal of Communication, 23 (March 1973), 17-46.

Bryant, Donald C. and Karl R. Wallace. Fundamentals of Public Speaking. 4th ed. New York: Meredith Corporation, 1969.

Budd, Richard W., Robert K. Thorp, and Lewis Donohew. Content Analysis of Communications. New York: The Macmillan Company, 1967.

Cohen, Rosalie A. "Conceptual Styles, Culture Conflict, and Nonverbal Tests of Intelligence," American Anthropologist, 71, No. 5 (October 1969), 828-856.

Condon, John C. and Fathi S. Yousef. An Introduction to Intercultural Communication. Indianapolis: The Bobbs-Merrill Co., Inc., 1975. 
Doi, Takeo. The Anatomy of Dependence. Tokyo: Kodansha Ltd., 1973.

Dyer, Frederick C. Executive's Guide to Effective Speaking and Writing. Englewood Cliffs: Prentice-Hall, Inc., 1962.

Ekman, Paul. "Face Muscles Talk Every Language," Psychologit Today, 9, No. 4 (September 1975), 35-39.

Ernst, Earle. The Kabuki Theatre. New York: Oxford University Press, 1956.

Gibson, Walker. "Hearing Voices: Tough Talk, Sweet Talk, Stuffy Talk," in The Speaker's Reader: Concepts in Communication. Edited by Robert I. Scott. California: Scott, Foresman and Co., 1969, 191-200.

Goffman, Erving. The Presentation of Self in Everyday Life. New York: Anchor Books, 1959.

Greeley, Andrew M. Why Can't They Be Like Us. New York: E. P. Dutton and Co., Inc., 1971.

Holsti, Ole R. Content Analysis for the Social Sciences and Humanities. Massachusetts: Addison Wesley Fublishing Co., 1969.

Johannesen, Richard I. "The Functions of Silence: A Plea for Communication Research," Western Speech, 38, No. 1 (Winter 1974), 25-35.

Kaplan, Robert B. "Cultural Thought Patterns in InterCultural Education," Language Learning, 16, Nos. 1 and $2,1-20$.

Katz, Elihu. Social Research on Broadcasting: Proposals for Further Development. Publicity and Information Department, British Broadcasting Corporation, 1977.

Katz, Robert I. Empathy: Its Nature and Uses. Iondon: The Free Press of Glencoe, Collier-Macmillan Ltd., 1963.

Knapp, Mark L. Nonverbal Communication in Human Interaction. New York: Holt, Rinehart and Winston, Inc., 1972 .

Kobayashi, Toshihiro. "Toward True International Exchange," Japan Echo, 3, No. 4 (1976), 141-144. 
Krivonos, Paul. D. and Mark I. Knapp. "Initiating Communication: What Do You Say When You Say Hello?"

Central States Speech Journal, 26, No. 2 (Summer 1975), 115-125.

Kunihiro, Masao. "The Japanese Language and Intercultural Communication," The Japan Interpreter, 10, Nos. 3-4 (Winter 1976), 267-283.

"Indigenous Barriers to Communication," ECT: A Review of General Semantics, XXXII, No. 3 (September 1975), 259-272.

McIuhan, Marshall. Understanding Media: The Extensions of Man. New York: McGraw-Hill Book Co., 1964.

Marsh, Patrick O. Persuasive Speaking. New York: Harper and Row, Publishers, 1967.

Miller, Larry D. "Dyadic Perception of Communicator Style: Replication, Confirmation, and Theory," a report to the Interpersonal Communication Division of the International Communication Association, Portland, Oregon, April 1976.

Moran, Louis J. "Comparative Growth of Japanese and North American Cognitive Dictionaries," Child Development, 44, No. 4 (1973), 862-865.

and Noriko Murakawa. "Japanese and American

Association Structures," Journal of Verbal Learning and Verbal Behavior, 7, No. 1 (February 1968), 176-181.

Morrison, John I. "The Absence of a Rhetorical Tradition in Japanese Culture," Western Speech, 36, No. 2 (Spring 1972), 89-102.

Morsbach, Helmut. "Aspects of Nonverbal Communication in Japan," in Intercultural Communication: A Reader. 2nd ed. Edited by Larry A. Samovar and Richard E. Porter. Belmont, California: Wadsworth Publishing Co., Inc., 1976, 240-248.

Mukai, Satoshi. "How Film Commercials Differ in Japan, U.S.," Dentsu's Japan Marketing Advertising (1975-76), $33-36$.

Nakane, Chie. Japanese Society. Berkeley: University of California Press, 1970. 
Kinship and Economic Organization in Rural Japan. London: University of London, Athlone Press, 1967:

Tokyo: Tekio no Joken [Conditions for adaptati

Nishiyama, Kazuo. "Speech Training for Japanese Businessmen," The Speech Teacher, 24, No. 3 (September 1975), $251-255$.

Norton, Robert w. et al. "Communication Style Correlates of Attraction, " a report to the International Speech Association Convention, Chicago, Illinois, April 1974.

Oliver, Robert T. "Asian Public Address and Comparative Public Address," The Speech Teacher, 23, No. 2 (March 1974), 101-108.

Pike, Kenneth L. Language in Relation to a Unified Theory of the Structure of Human Behavior, 2nd ed. rev. The Hague, Netherlands: Mouton and Co., Publishers, 1967.

Real, Michael R. Mass-Mediated Culture. Englewood Cliffs: Prentice-Hall, Inc., 1977.

Reischauer, Edwin 0. The Japanese: Cambridge: Harvard University Press, Belknap Press, 1977.

The $\frac{\text { The United States }}{\text { Viking Press, } 1965 .}$

Richards, Leverett. "17.7 Million Bid by Japanese Firm OKd for Drydock," The Oregonian, 16 september 1977.

Sarett, Alma Johnson et al. Basic Principles of Speech. Boston: Houghton Mifflin Co., 1966.

Scheflen, Albert. How Behavior Means. New York: Anchor Books, 1973.

Scott, A. C. The Puppet Theatre of Japan. Rutland, Vermont: Charles E. Tuttle Co., 1963.

Scott, Robert I. The Speaker's Reader: Concepts in Communication. Palo Alto: Scott, Foresman and Co., 1969. 
Scott, William A. "Reliability of Content Analysis: The Case of Nominal Scale Coding," Public Opinion Quarterly (Fall 1955), 321-325.

Sibley, Mulford Q. "The Traditional American Doctrine of Freedom of Thought and Speech," in the American Culture. Edited by Henning Cohen. Boston: Houghton Mifflin Co., 1968, 168-178.

Siegel, Sidney. Nonparametric Statistics for the Behavioral Sciences. New York: McGraw-Hill Book Co., Inc., 1956.

Stanhope, Philip D. Speech. Edited by Robert C. Jeffrey and Owen Peterson. New York: Harper and Row, Inc., 1975.

Stewart, Edward C. Dimensions of International Education. No. 3. American Cultural Patterns: A Cross-Cultural Perspective. Pittsburg: Regional Council for International Education, 1974.

Thomson, John R. "How Coca-Cola's Hi-C Scored Success in Japan," Advertising Age (Nov. 29, 1976), 44-46.

Triandis, Harry C. The Analysis of Subjective Culture. Canada: John Wiley and Sons, Inc., 1972.

Tsujimura, Akira. Japanese Culture and Communication. Tokyo: Nihon Hoso Shuppan Kyokai, 1973.

Umesao, Tadaa. "Escape from Cultural Isolation," the wheel extended, IV, No. 3 (Winter 1974), 4-Il.

Van Zandt, Howard F. "How to Negotiate in Japan," in Intercultural Communication: A Reader. 2nd ed. Edited by Larry A. Samovar and Richard E. Porter. Belmont, California: Wadsworth Publishing Co., Inc., 1976, 307-318.

Watzlawick, Paul et al. Pragmatic of Human Communication: A Study of Interactional Patterns, Pathologies, and Paradoxes. New York: W. W. Norton and Co., Inc., 1967.

Zax, Melvin and Shigeo Takahashi. "Cultural Influence on Response Style: Comparisons of Japanese and American College Students," The Journal of Social Psychology, 71 (1967), 3-10. 
Interviews

Gamo, Toyosuke, Vice President and General Manager, Dentsu Corporation of America, August 9, 1977.

Karr, Chadwick and James A. Paulson, Dept. of Psychology, Portland State University, November 1977.

Katz, Elihu, Professor, Hebrew University, at The Annenberg School of Communication, University of Southern California, August 9, 1977.

Letters

Maeda, Jiro. International Relations, Mainichi Broadcasting System, Inc., Isaka, Japan, April 4, 1977. 
APPENDIX A

DIRECTIONS FOR JUDGES, AND SCORING SHEET 


\section{DIRECTIONS FOR JUDGES}

After you observed each TV commercial, please assign each commercial to a set of categories in each scoring sheet. Each category is defined as follows:

\section{Character Actor}

Category 1: Celebrity, Authority

Primary method of presenting a product is that a celebrity or a professional gives information about a product as an authority in the field, or expresses his personal feelings about a product.

Category 2: Consumer Testimonial

Primary method of presenting a product is that a consumer interviewed by an announcer indicates the product's usefulness.

Category 3: Announcer, Narrator

Primary method of presenting a product is that a person or persons representing the company gives information about a product.

Category 4: Animation

Primary method of presenting a product is by a cartoon or animated form, such as an inorganic product presented as a living object which provides product information about the person. 
Category 5: Dramatization

Primary method of presenting a product is by an actor who is used to introduce a product in a fictitious story.

Category 6: Musical Production

Primary method of presenting a product is by singing and/or dancing which provides information about the product.

\section{Explicitness of Content}

Category 1: Primary means of presentation of a product in this category are that description, function, value, and use of a product are explicitly stated or shown visually. Therefore, the majority of content in this type of TV commercial is product information.

Category 2: Primary means of presentation of a product in this category is that product information is not explicitly stated; rather, the information is inferred and more ambiguous, and the content of a TV commercial is sometimes focused on more social and cultural aspects in everyday life. An advertised product is either implied or shown in context. 


\section{Tone of Voice}

Category 1: Primary vocalized sound in the presentation of a product is humorous, comical, nonsensical, escapist, or dreamy.

Category 2: Primary vocalized sound in the presentation of a product is serious, realistic, or straightforward.

Category 3: Primary vocalized sound in the presentation of a product is the mixture of the two kinds of tone which are classified in the categories 1 and 2 . 


\section{SCORING SHEET}

JAPANESE: US COMMERCIAI \#

I Character of Actor or

Presenter

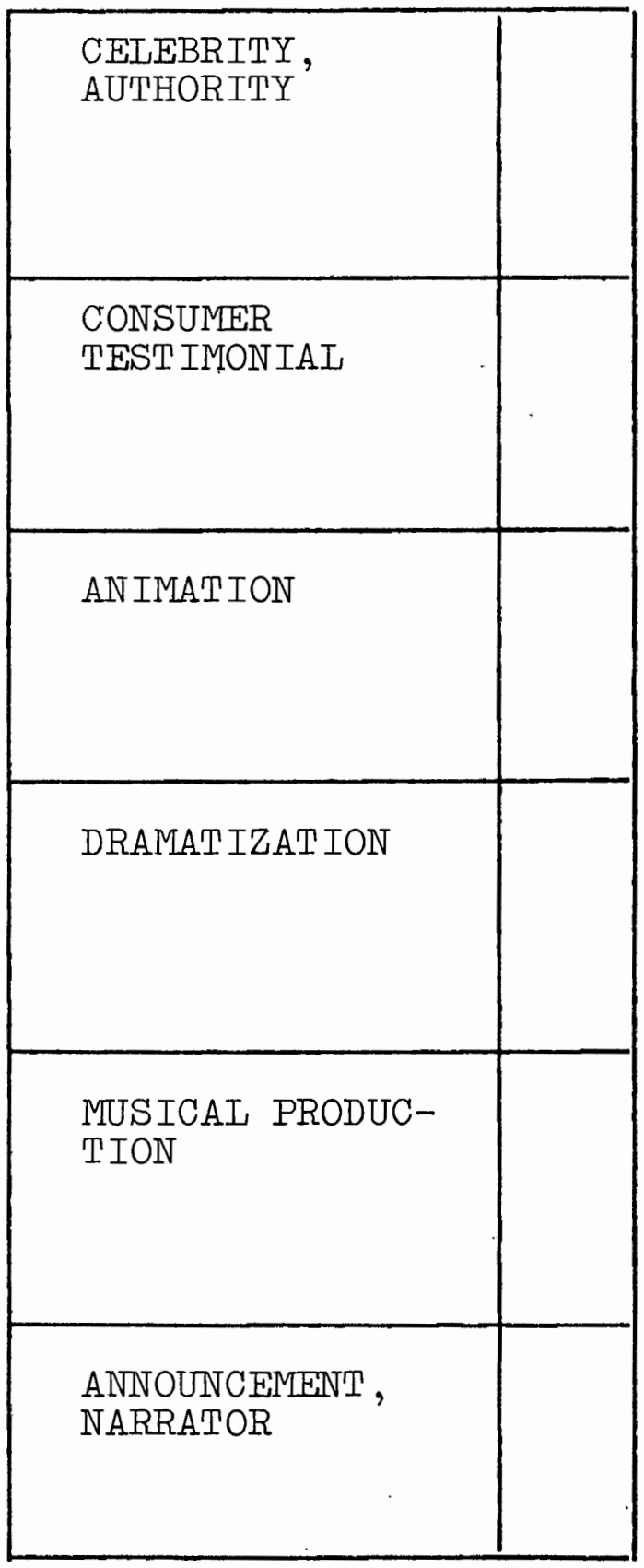

\section{Content}

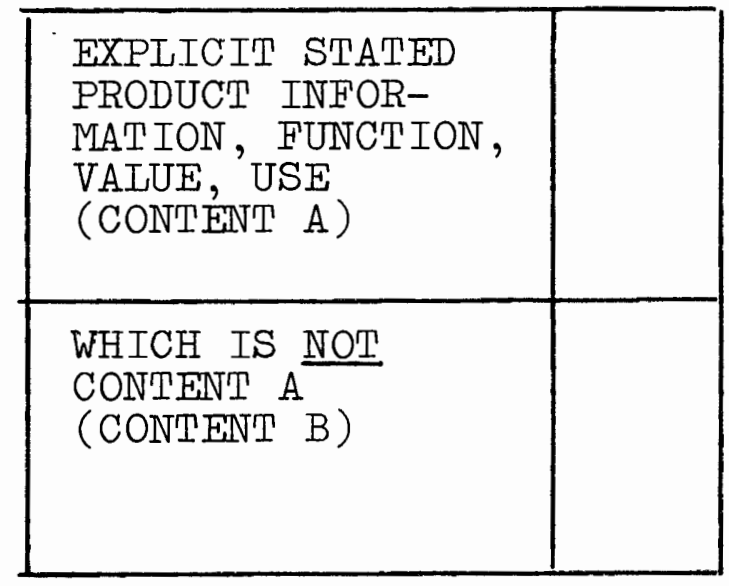

\section{Tone of Voice}

HUMOROUS, COMI-

CAI, NONSENSI-

CAI, ESCAPIST

SERIOUS, REALISTIC, STRAIGHTFORWARD

MIXTURE 


\section{APPENDIX B}

IIST OF JAPANESE AND AMERICAN TELEVISION COMMERCIALS 
1 Toshiba-Kokage (air conditioner)

2 Kodak-Instamatic (camera)

3 Nankai Dentetsu Group (company-group)

4 Iyons Maid (ice cream)

5 Vitawan (dog food)

6 Kappucho (crackers)

7 Seiko (watch)

8 Chicken Ramen (noodle)

9 Iona (cosmetics)

10 Haig (scotch)

11 Del Monte (tomato ketchup)

12 Kanebo (cosmetics)

13 National (illumination)

14 Shiseido (cosmetics)

15 Band-Aid (small bandages)

16 Max Factor-Pancake (cosmetics)

17 Brawn Syneron (electric razor)

18 Asahi (soy bean cake)

19 Hitachi (refrigerator)

20 Taisho-Gokiburizorozoro (insecticide)

21 Takeya (miso-paste)

22 Kukku-Machikku (micro-oven)

23 Bean Product Association (company-group)

24 Kirin (tomato juice)

25 Sujata P (cream-dairy product)

26 Taiyaton F (remote control)

27 Shanpon Yangu (sanitary napkin)

28 House-Jawa Curry (curry sauce)

29 Takeda-Shintakeda Ichoyaku (medicine)

30 Adachi (Fine Jewelry store)

31 Marudai-Akamiso (miso paste) 
32 Kirigamine (air conditioner)

33 Shokudoen (restaurant)

34 Minokichi (restaurant)

35 Ina (floor tile)

36 Coke (soft drink)

37 Kanden (electric company)

38 Taikei (construction company)

39 Nissan (furniture)

40 Kirin Orange (soft drink)

41 Kirin Lemon (soft drink)

42 Hi-C Edo (soft drink)

43 Minoruta-Pikkato (camera)

44 Minoruta-16mm Sound (camera)

45 Kubota (company-group)

46 Neac-System 100 (computer)

47 Sumitomo-Kaiyo (insurance)

48 Toyosasshi

49 Universal Geneave (watch)

50 Oguraya Yamamoto (seaweed) 


\section{AMERICAN TELEVISION COMMERCIALS}

1 Karastan (floor tile)

2 Archway Cookies

3 Rico's Pizza (restaurant)

4 Chrysler Le Baron (car)

5 Sea Pak (frozen food)

6 Chevrolet Nova (car)

7 Milwaukee Beer

8 Yuban Coffee

9 S. J. Pounder (company)

10 Subaru (car)

11 Glidden Spred Paint (house paint)

12 Aqualia Moisture (cosmetics)

13 Insulspray (insulation)

14 Jeno's Pizza (pizza)

15 Columbia Optical (glasses)

16 Champagne Volkswagon (car)

17 Seiko (watch)

18 Presto (electric appliances)

19 Continental Insurance (insurance group)

20 Scramblers (food)

21 Edison Electric Institute (company)

22 Total (cereal)

23 Wheat Thin (crackers)

24 Krylon Paint Spray (house paint)

25 Avon (cosmetics)

26 Cinnamon Nut Cereal (cereal)

27 Skippers Fish 'n Chips (restaurant)

28 Nelson's Tire Warehouse (tires)

29 Rea Rose Tea Bagis

30 Soft Scrub (Detergent)

31 Continental Airline (company-group) 
32 Shasta (soft drink)

33 McRobert Ford (car)

34 Wizard Charcoal Lighter (lighter fluid)

35. Zale's (Fine Jewelry store)

36 Ogilvie (home permanent)

37 Mealtime (dog food)

38 Levitz (furniture)

39 7-Up (soft drink)

40 Mr. Steak (restaurant)

41. Hallmark Cards (greeting cards)

42 Anacin (medicine)

43 Post Grape Nuts (cereal)

44 Country Time Lemonade (soft drink)

45 Selsun Blue (shampoo)

46 Wheaties Cereal (food)

$47 \mathrm{Hi}-\mathrm{C}$ (soft drink)

48 Bell System (company)

49 Geritol (medicine)

50 Final Net (hair spray) 
APPEND IX C

MODIFICATION OF SCOTT'S $\pi$ 
MODIFICATION OF SCOTT'S $\pi$

TABIE XI

CONTINGENCY TABLE FOR JUDGE A AND B

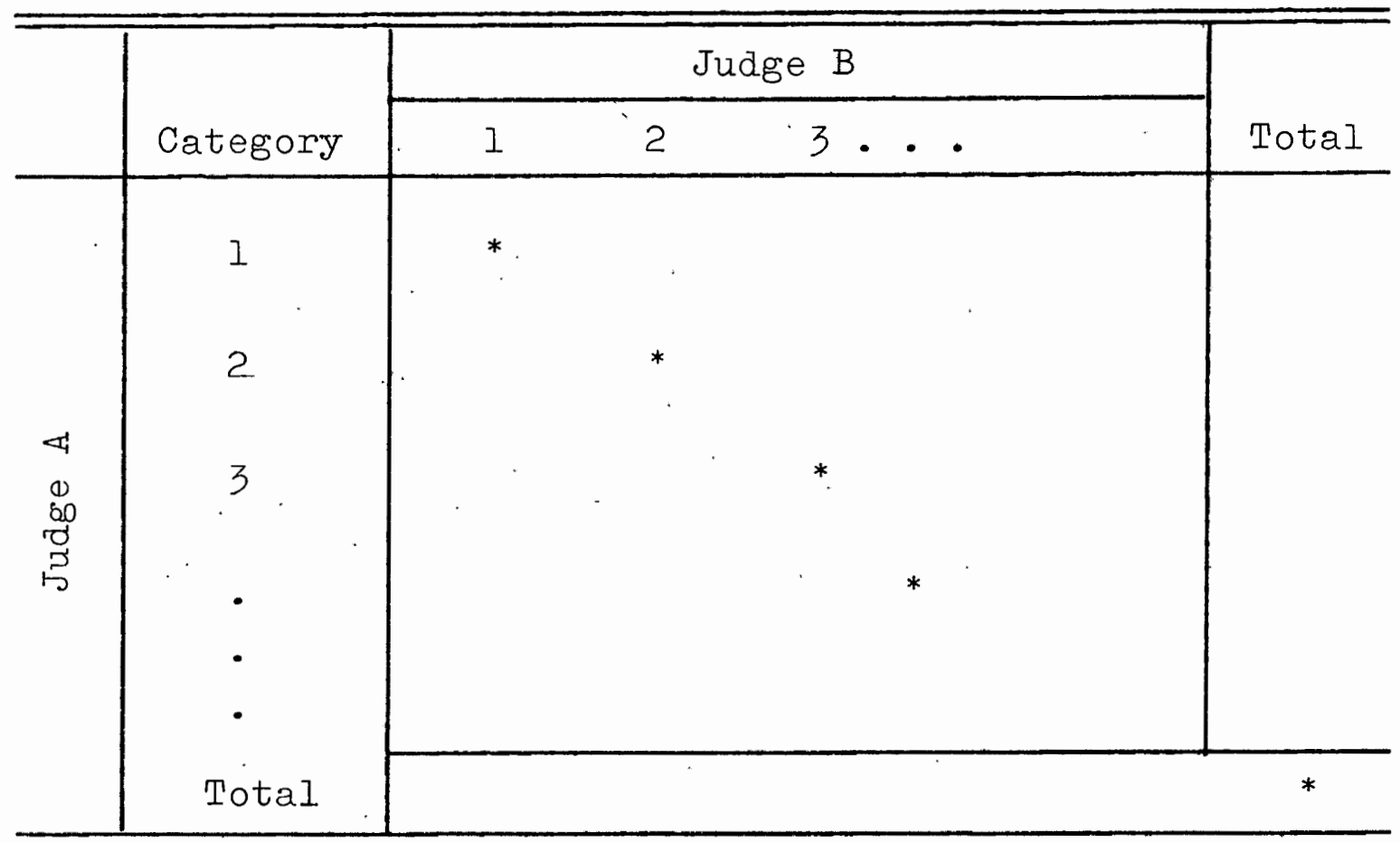

* cells are "agreeing" cells

Expected Agreement $=$ Sum of Row Proportion $X$ Column Proportion for Agreeing Cells

Observed Agreement $=$ Sum of Proportions in Agreeing Cells

Modification of $\quad=$ Observed Agreement - Expected Agreement Scott's $\pi$. Expected Agreement 